\title{
Accumulating through food crisis? Farmers, commodity traders and the distributional politics of financialization
}

\author{
JOSEPH BAINES \\ King's College London, Department of European and International Studies, London, United Kingdom \\ joseph.baines@kcl.ac.uk
}

This is an Author's Accepted Manuscript of an article published in the Review of International Political Economy, March 2017, [copyright Taylor \& Francis], available online at:

http://www.tandfonline.com/doi/full/10.1080/09692290.2017.1304434

\begin{abstract}
This paper considers the domestic and international ramifications of financialization and grain price instability in the US agri-food sector. It finds that during the recent period of high and volatile prices, the average income of large-scale farms reached the earnings threshold of the top percentile of US households, and agricultural commodity traders markedly outperformed other major corporate groups. In contrast, small-scale farms, particularly those involved in cattle and wheat production, have struggled to manage the uncertainty brought by price tumult. The paper goes on to examine the role that these uneven distributional dynamics play in debates around how hedging and speculation should be defined and regulated in the wake of the food crisis of 2007-08. It shows that a coalition of small-scale farmers has actively pushed for a far-reaching definition of speculation and concomitantly wide-ranging curbs on what they deem to be speculative activity. Conversely, the major commodity traders and a plurality of organizations representing large-scale grain producers have called for a narrower interpretation of speculation which leaves the extant regulatory regime largely in place. With these insights I suggest that financialization and associated price volatility tend to reinforce inequality in rural America while possibly exacerbating social instability and hardship abroad.
\end{abstract}

Keywords: Financialization; derivatives regulation; food regimes; food crisis; commodity trading; agriculture. 
'Stability, gentlemen, is the only thing we can't deal with.'

- Chicago Board of Trade official in conversation with agribusiness executives (cited in Lappé, 1981)

From 2007 to 2008, food prices surged. In response, people in over 25 countries demonstrated, rallied and rioted to express their discontent not only with the higher costs of living, but also injustice and inequality more broadly (Bush 2010). There was another bout of rapid food price inflation in 2010-11 which provoked a second round of civil unrest, as most clearly manifest in the Arab Spring (Bush and Martiniello 2017). Although food prices have since subsided, they are still well above the average level for the last three decades. In the meantime, many of the political uprisings of the Arab Spring have given way to heightened authoritarian rule or devastating civil war. Moreover, households across the Global South have been pushed into doing more paid work and consuming less nutritious food to make ends meet, with the burden of adjustment falling particularly heavily on women (Scott-Villiers et al. 2016).

Food price swings therefore matter as they can contribute to wide-ranging geopolitical shifts as well as profound changes in everyday life for people across the world. And according to many analysts, speculative activity can exacerbate such price swings. Amid growing international concern regarding the possibly destabilizing role of speculation, the US Congress conducted a series of investigations on commodity derivatives markets (US Senate, 2006, 2007, 2009). These studies concluded that 'excessive speculation' in commodity derivatives markets - especially via commodity index funds (CIFs) - was indeed a key driver of high and volatile prices. Other derivatives markets, not directly linked to physical commodities, also aroused acute anxiety. In particular, many believed that the over the counter (OTC) trade in credit default swaps amplified the wave of defaults in the US mortgage sector into the tsunami of financial failure that engulfed the global economy in 2007-08. It was in this context that the Dodd-Frank reform agenda was conceived. Hailed as the most far-reaching overhaul in financial regulation since the New Deal, the 2010 Dodd-Frank Act mandated sweeping changes, including the imposition of new caps, known as position limits, on the amount of futures contracts that speculators can hold. However, despite the fanfare that surrounded the Act's promulgation, the implementation of position limits has long passed the deadline of April 2011 set by Congress.

With reference to the vexed birth of the new position limit regime, this paper enquires into whether there are any groups that benefit from price instability within US agri-food supply chains, and if so, whether these groups have been resisting regulatory attempts at curbing potentially destabilizing speculative flows. Admittedly, a more thorough analysis of the evolution of commodity derivatives would offer a close examination of the crucial role played by corporations outside of the agri-food sector in reform debates, and it would also draw on the rich insights offered by those who have analyzed financial 
regulatory policymaking dynamics in interstate and transnational policy arenas (e.g. Moschella 2010; Tsingou 2015). However, this paper limits its focus to the producers and distributors of agricultural products so as to clarify aspects of the financialization of agriculture that have not yet been fully explored in the existing literature. Specifically, the paper makes three key contributions. Firstly, it is the first explicit attempt to connect changes in the regulation of derivatives markets to shifts in 'food regimes' - the rulegoverned structures that shape the production, distribution and consumption of food (Friedmann and McMichael 1989). Secondly, it points to how the regulatory reinterpretation of hedging and speculation helped spur the financialization of agricultural markets, and it thus contributes to literature on the discursive reconstruction of the hedging-speculation dichotomy (see Engel 2013). Thirdly, it responds to recent calls to advance a more differentiated analysis of farmers' interests in relation to the contemporary financialization of agricultural markets (Williams 2014). Although there has been important work done in this area by scholars analyzing the expansion of derivatives markets in the Global South (e.g. Breger Bush 2012; Isakson 2015; Newman 2009), less attention has been given to the variegated impacts of price instability, and associated dynamics of financialization, on farmers in the Global North.

At a broad level, the analysis of interests in the US agri-food sector is especially significant because the United States can be seen as an epicenter of financialization and the associated price tumult that has rippled throughout the world. Indeed, the first major CIF - the eponymous Goldman Sachs Commodity Index - was designed by a USheadquartered bank. The first major deregulatory measures that allowed CIFs to flourish were passed by US policymakers. Some of the world's largest grain futures trading venues are located in the United States. And the United States dominates the export of the three most widely traded agricultural commodities on the planet - corn, soybeans and wheat - accounting for 42, 38 and 22 percent of global export tonnage of each respective commodity (FAOSTAT 2014). From this perspective, struggles in the field of US commodity derivatives regulations assume a particular importance. As I show, the agricultural groups that are most negatively affected by market instability - namely small-scale farmers, particularly those involved in cattle and wheat production - have promoted regulatory attempts to curb speculative activities, and have called for a broad regulatory interpretation of speculation and concomitantly narrow exemptions from position limits. In contrast, the agricultural groups that are most capable of prospering during instability - namely agricultural commodity traders and large-scale farmers have been highly resistant to proposed curbs and have called for an expansive regulatory interpretation of hedging and correlatively broad exemptions from position limits.

The paper is divided into three sections. Section 1 draws on historical institutionalist scholarship to offer a power-distributional perspective on financialization and food regime shifts. In particular, it describes the supersession of the collective system of risk management set up during the New Deal era in the 1930s by private forms of risk management from the 1970s onward; and it highlights the ways in which the regulatory redefinition of hedging and speculation facilitated the growth of derivatives trading in agricultural markets. Section 2 illuminates the differential effects of high and volatile 
prices that have accompanied the financialization of the US agri-food sector. Finally, section 3 examines agricultural interest group conflicts around the scope of new position limits mandated by the 2010 Dodd-Frank Act, and it draws out the international implications of these conflicts.

\section{A POWER-DISTRIBUTIONAL PERSPECTIVE ON FINANCIALIZATION}

Financialization has manifold meanings (see Clapp 2014; Isakson 2014; van der Zwan 2014). But this paper restricts the use of the term to a particular process: the growth of agricultural derivatives markets relative to underlying agricultural production. Figure 1 shows that the financialization of agricultural markets has been far from unilinear. Specifically, the top chart presents data on the levels and volatility of grain futures prices from the 1880s to the contemporary period. The bottom chart relays data on the volume of cereal grains produced in the United States and the volume of cereal grain contracts traded in futures markets. And the middle chart divides these two series to yield what can be called the 'financialization ratio'. This metric reveals how many bushels of grain are traded on US futures markets for every physical bushel of grain produced in the United States. The figure clearly shows that the degree of financialization and the level of price volatility in agricultural markets are broadly concordant. After being at an elevated plane for much of the late nineteenth and early twentieth centuries, the level of futures trading relative to physical production declined to an almost one-to-one ratio from the 1940s to the 1960s, just when agricultural price volatility fell to historic lows. Since this period there has been a surge in the financialization of US agriculture and a concurrent amplification of price volatility. Indeed, in recent years, one can see that for every bushel of grain produced by US farmers, approximately 33 bushels of grain are traded on US futures exchanges; and in the last commodity price spike in 2010-11, volatility was at its highest point in four decades.

In order to make sense of the de-financialization of agricultural markets in the 1930s and their re-financialization from the 1960s onwards, this papers draws on the powerdistributional approach to institutional change propounded by historical institutionalist scholars (Mahoney and Thelen 2010). At its most fundamental level, this approach draws our attention to the fact that institutions are legacies of past social struggles and instruments of ongoing redistribution. Moreover, from the power-distributional perspective, institutional change occurs not only because of distributional conflicts around institutions' uneven allocation of costs and benefits across groups, but also because institutional rules are oftentimes ambiguous and therefore open to contestation. To be sure, as James Mahoney and Kathleen Thelen (2010: 11) argue: '[c]oalitions form not only as representatives of alternative institutions but also as 


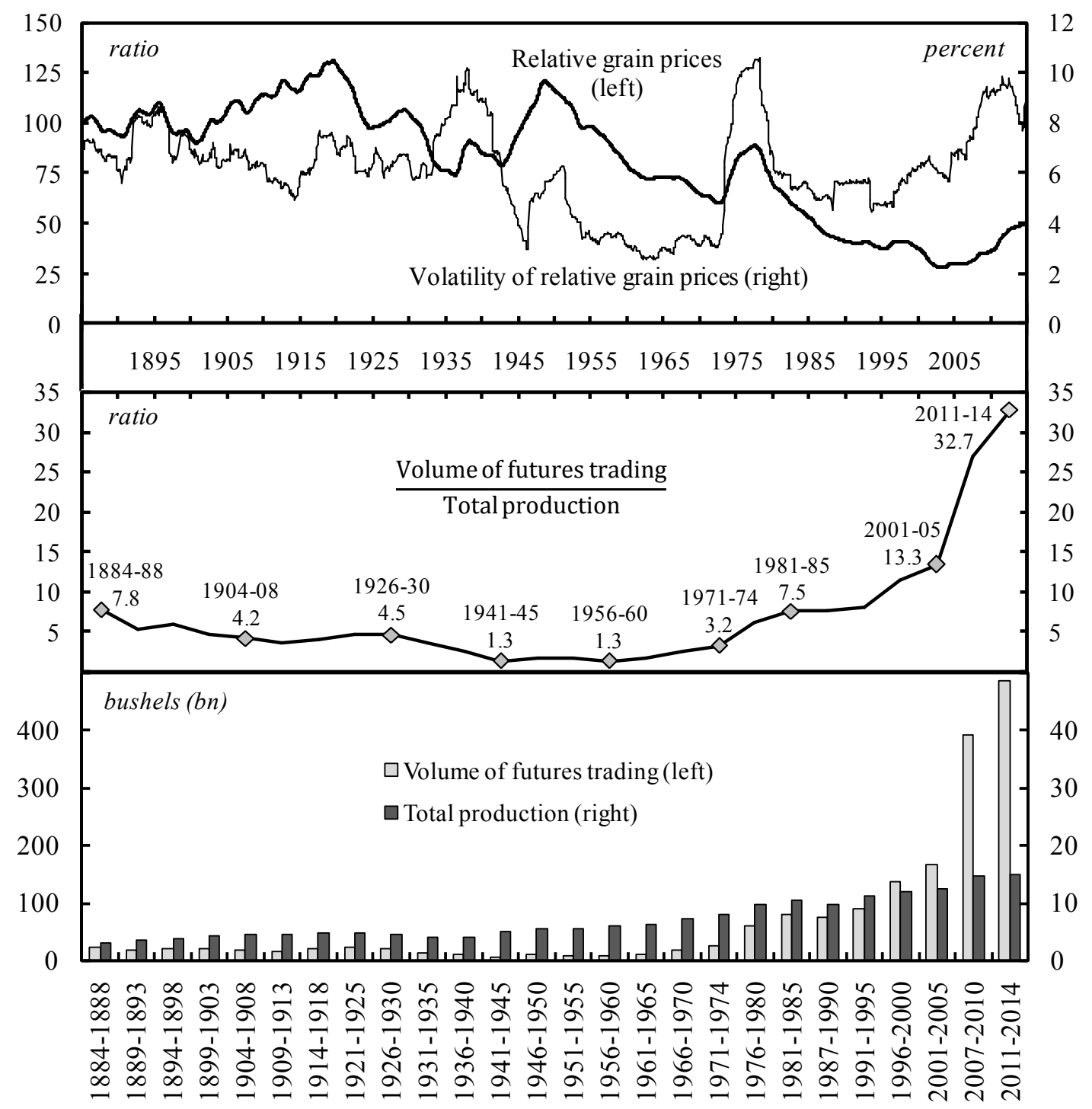

Figure 1: Historical Dynamics of Financialization and Grain Price Instability 1884-2014

Notes: Relative grain prices are calculated by dividing the unweighted average of the Wheat no.2 price, the Chicago Yellow corn no.2 price, and the soybean cash price by the Producer Price Index - All Commodities. Relative price data are presented as 5-year moving averages. Volatility of relative grain prices is the standard deviation of the monthly rate of change of the relative grain price data in a 5-year moving window.

Source: Price data from Global Financial Data. Series codes for wheat prices, corn prices, soybean prices and Producer Price Index: W_USSD; C_US2D; SYB_TD; and WPUSAM. Volume of futures trading data from Hieronymous (1976: 23), CFTC (1979-2004), Burghardt and Acworth (2008: 28), Acworth $(2011,2014,2015)$. Grain production data from Carter (2006) and USDA (2016b; 2016c). 
movements seeking particular interpretations of the ambiguous or contested rules of a given institution'. As a corollary, those groups that are most equipped to foresee the uneven outcomes of specific institutional configurations will be best positioned to push for particular interpretations of rules that favor them. In contrast, those groups that are least equipped to foresee the distributional outcomes may not contest the interpretation of extant institutional rules at all. As such, the conflicts that drive institutional change stem both from perceptions of the uneven distributional effects of any given institution and the openness of institutional rules to reinterpretation (Mahoney and Thelen 2010; Streeck and Thelen 2005). The remainder of this section examines the distributional conflicts and rule interpretations that gave form to two institutional regimes governing the organization of cash markets and derivatives markets over the last century. The first is the state-managerial food regime that emerged in the 1930s, that reached the peak of its institutional coherence in the 1950s, and that largely disintegrated in the 1960s and 1970s. And the second is the financialized food regime that developed around the most durable institutions of the previous regime, and that continues to this day.

\subsection{The state-managerial food regime}

Speculation in futures markets has been criticized by agricultural groups ever since the founding of the Chicago Board of Trade (CBOT) in 1848. Specifically, option contracts aroused disquiet for they were widely viewed as gambling devices that undermined the proper functioning of commodity markets. In addition, there was anxiety regarding the downward pressure potentially exerted on prices by speculative short-selling. These concerns initially led to abortive attempts by state legislatures to ban futures speculation. By the 1890s, in the context of a long-running depression in agricultural prices and a wave of populist agitation against speculators, restrictions on speculation were considered at the federal level. But due to insufficient congressional support and significant judicial opposition, no curbs on speculation were enacted in the years leading up to the First World War (Markham 2014).

However, after an upsurge in agricultural prices during the war, deflation returned with a vengeance and agricultural lobbying organizations professionalized their advocacy efforts. Farm organizations such as the National Farmers Union called for farreaching restrictions on speculation not only to quash short-selling activities but also to undermine those agricultural commodity traders that enjoyed oligopolistic control over Midwestern elevator operations. Through pushing for curbs on speculation, these farm organizations wagered that they could undermine one of the key institutions of the grain trade - the futures market - and in so doing, boost the control of farm cooperatives over the agricultural marketing system. As very few farmers used futures to hedge agricultural price risk, many believed they would not be negatively impacted by curbs to futures markets (Pashigian 1988; Romano 1997).

The 1929 Wall Street Crash shifted the legislative terrain in favor of farm organizations, as it appeared to offer legitimacy for those seeking to restrain speculators 
in both stock markets and futures markets. Moreover, the ensuing depression in agricultural prices spurred the federal government into providing more substantial economic security for farmers in cash markets. In this context, two major legislative initiatives were enacted. Under the 1933 Agricultural Adjustment Act, the US government established a comprehensive system of price supports, production controls, and public grain storage known as the 'ever normal granary', so that farmers were protected from sudden income drops. And under the 1936 Commodity Exchange Act, the use of option contracts was banned for all market participants in registered exchanges and position limits on speculation were inaugurated to cap the trading of all but those engaging in bona fide hedging. In the terms of the power-distributional approach, then, the turmoil of the interwar years had heightened farmers' and other societal groups' perceptions of the uneven distributional outcomes of existing institutional arrangements and, in line with the resulting mobilization and institutional changes, there was a shift in the balance of power away from agricultural commodity traders as well as Wall Street banks. ${ }^{1}$

By the end of the Second World War, this domestic balance of power was supported by a complementary international environment that the US government actively cultivated. In particular, the Bretton Wood system of pegged exchange rates and capital controls helped the US government to continue to meet the demands of agricultural groups, among other domestic constituencies, without the risk of provoking destabilizing currency movements. And the exemptive status afforded to agriculture in the 1947 General Agreement on Tariffs and Trade couched domestic supply management into an overarching system of managed trade. The system was based on intergovernmental accords such as the 1949 International Wheat Agreement and the 1968 International Grains Arrangement, which sought to regularize agricultural prices and trade flows. These accords also reflected the primacy of Keynesian economic ideas as John Maynard Keynes himself lent his firm backing to international commodity price stabilization. The domestic and international arrangements that emerged as a result of these ideas facilitated the development of what can be called a state-managerial food regime. In response to the distributional conflicts accompanying the Wall Street Crash and the Great Depression, the distinct social purpose of this regime was to curb speculation, collectivize risk and stabilize prices (Newman 2009; Winders et al. 2015).

The changing contours of physical markets during the state-managerial food regime are displayed in Figure 2. The main chart tracks the amount of US wheat and corn supply in storage as denominated in days of overall usage, and the left insert offers information on the proportion of grain stocks held by the US government. The figure suggests that the state-managerial food regime peaked in the late 1950s and early 1960s, when US wheat stocks had expanded to over one year's worth of supply, while corn stocks crept up to nine months of supply. Over two-thirds of the wheat stocks and almost one half of the corn stocks were held in government storage during these two decades (see left insert of Figure 2). The US government sought to relieve itself of these surpluses principally through a food aid program, authorized by the 1954 Public Law 480, which disbursed vast quantities of grain and other agricultural commodities to Third World nations at the 


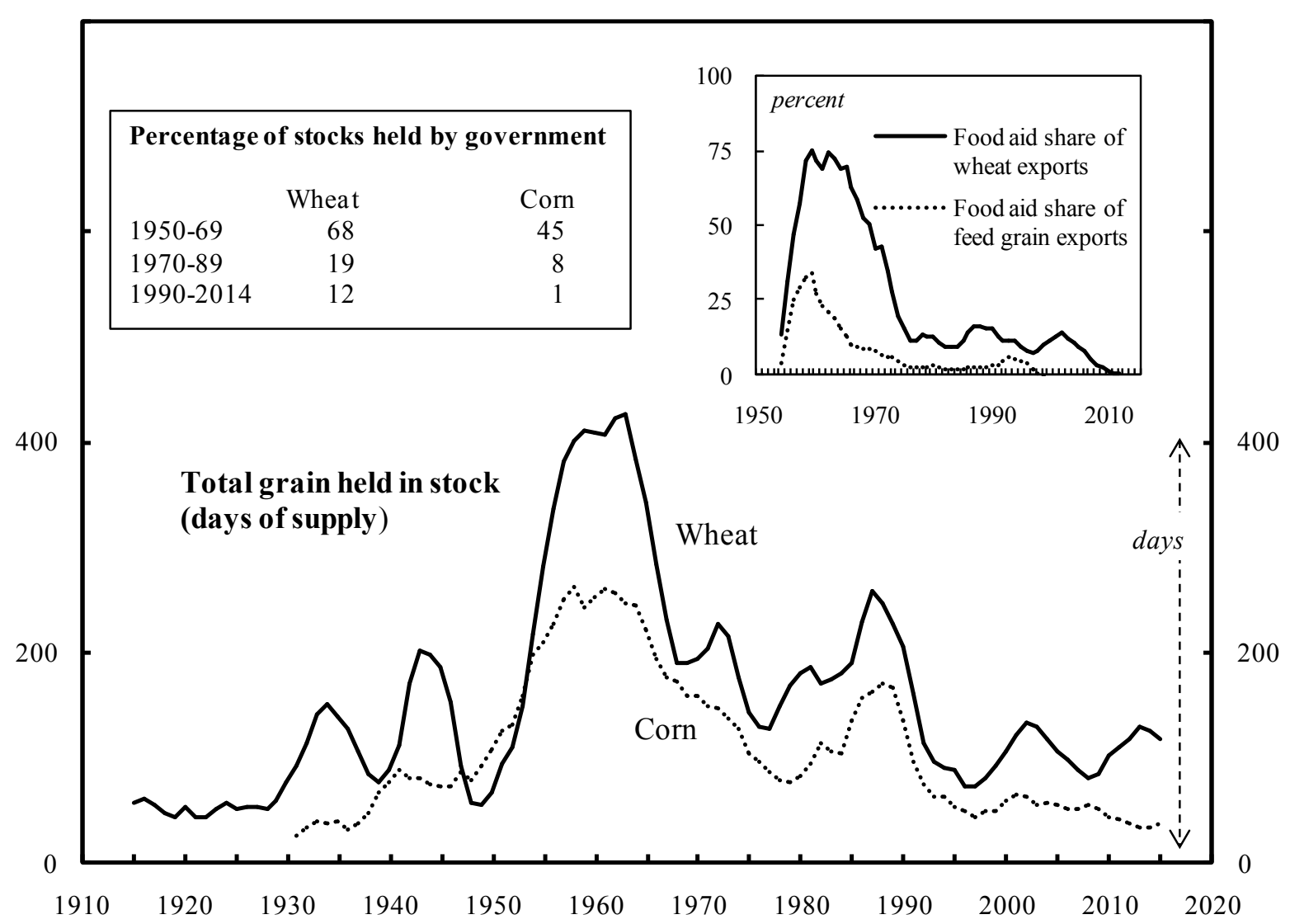

Figure 2: Historical Trends in US Grain Storage and Food Aid, 1915-2015

Notes: Days of grain supply held in stock is calculated by the dividing end stocks by the amount of grain used in the marketing system each year (known as 'total disappearance') and multiplying by 365 . The data in the charts are presented as 5-year moving averages. Food aid data do not include the aid from the Marshall Plan that preceded the PL 480, as no relevant information appears to be available on US food aid prior to 1954.

Source: US grain stocks, government storage, export and aid data from USDA $(1941 ; 1961 ; 1967 ; 1971$; $1976 ; 1981 ; 1986 ; 1991 ; 1996 ; 2016 b ; 2016 c)$.

frontier of the Cold War. Astonishingly, as the right insert of Figure 2 shows, from the late 1950 s to the early 1960 s, 75 percent of the US's wheat exports came in the form of food aid. The system of managed trade and risk collectivization rendered the trading of futures contracts unnecessary for many agricultural groups that sought protection from tumult and unprofitable for those speculators who hankered for market swings. It is due to these factors that the volume of futures trading relative to underlying agricultural production fell to historic lows in the early post-war period. 


\subsection{The financialized food regime}

However, by the 1960s, the state-managerial food regime was beginning to unravel. On a domestic level, the broad farm coalition that originally supported the New Deal reforms began to fracture. In particular, agricultural interests in the South were critically weakened by the success of the Civil Rights movement in undermining the institutional basis of southern white supremacy and in broadening the franchise in African American communities. These historic achievements led the Democratic Party to pivot away from its traditional southern agrarian electoral base toward racialized constituencies that had been marginalized from the benefits of state-managerialism. Moreover, in the Midwest, large-scale farmers became increasingly frustrated with the farm program on the grounds that production controls represented a fetter on their income growth. Similarly, agribusiness interests were also becoming increasingly vocal in their opposition to the New Deal social compact on the grounds that they too felt hamstrung by supply management (Bonnen et al. 1996; Winders 2009).

The state-managerial food regime was weakened further by developments on an international level. In particular, agricultural commodity traders increasingly sought to circumvent the system of managed trade that prevailed in post-war agricultural markets, as was most clearly evidenced in a series of secretive blockbuster grain deals with the Soviet Union in 1972. It was in this period that the International Wheat Agreement was abandoned, and that the statist structures that defined the trading patterns of the early Cold War era began to be superseded by the eminently global interests of agri-food corporations (Friedmann 1993). But perhaps most importantly, the Bretton Woods system collapsed in 1971 following a decade and a half in which financial entities circumnavigated capital controls. As a consequence of the demise of the post-war monetary order, agricultural prices became unmoored from the fixed dollar-gold anchor, and administered prices were no longer considered viable at a domestic level. The US government's response to these new circumstances came in the form of the landmark 1973 Farm Bill as it initiated the dismantling of the comprehensive system of regulations enacted in the New Deal era (Schuh 1974). Set-aside requirements were suspended, farm price supports were undercut, and the US government continued its retreat from grain storage. Moreover, the decline of managed trade proceeded apace due to the partial and highly uneven liberalization of agriculture inaugurated by the Uruguay Round of Trade negotiations from 1986 to 1994 and the resulting WTO Agreement on Agriculture. ${ }^{2}$ The Agreement reinforced pressures from the World Bank and IMF structural adjustment programs on governments in the Global South to eliminate their grain reserves (Patel and McMichael 2009). Thus, having been rendered increasingly dependent on grain imports by vast food aid shipments from the United States in the post-war era, developing countries were now encouraged to dismantle their main institutional buffer against grain price swings, just as public grain stocks in the United States were themselves drawn down (see Figure 2). Due to these domestic and international shifts, market volatility has risen dramatically and grain exchanges experienced a massive increase in trading activity among those seeking protection from the price fluctuations 
and those seeking to speculate on them (Strange 1988). The pooling of risk initiated in the New Deal era has thus become superseded by private forms of risk management mediated by derivatives markets. In consequence, a new 'financialized food regime' has emerged (Burch and Lawrence 2009).

The rise of this regime was also engendered by a series of incremental changes in the interpretation of rules that have undergirded the regulation of derivatives markets in the United States ever since the 1936 Commodity Exchange Act, and that have been replicated in other countries. Of particular interest here is the broadening regulatory definition of bona fide hedging as it increased the range of activities that were made exempt from trading caps. Figure 3 summarizes how the line between hedging and speculation has been redrawn by regulators since the inauguration of the position limit regime. As the figure shows, the first major change in the interpretation of hedging took place in 1956 when the USDA classified anticipatory hedging - in which a futures position is held in order to cover an anticipated rather than guaranteed cash market transaction - as a legitimate risk-reducing activity to be made exempt from speculative limits (Paul 1976). By no longer restricting exemptions to those entities that sought to offset formal merchandising commitments, this regulatory change in futures markets gave more leeway for commercial entities to offset the risks associated with expected, rather than guaranteed, transactions in physical markets. However, the regulatory change also gave latitude to those that wanted to engage in profitable price-bets without having to make prior cash commitments. The second incremental shift occurred well after the collapse of the state-managerial food regime, in 1977, when cross hedging - in which a futures position in one commodity is used to cover the risk exposure in another commodity - was also reclassified as bona fide hedging. Again, this provided more room to those commercial entities to reduce their price risks, especially if the commodity that they traded in cash markets did not have an equivalent in futures markets; but it also increased the opportunities of those that sought to bet on cross-commodity price spreads to evade speculative limits. Moreover, in 1982, the CFTC began a program to reverse the ban on options trading instituted by the 1936 Commodity Exchange Act. The reappraisal of what were formerly considered to be instruments of speculative gambling as legitimate tools for risk management indicated just how far the regulatory interpretation of the ambiguous dividing line between hedging and speculation had shifted (Berkovitz 2009; Breger Bush 2012).

In the context of the development of portfolio management theory from the 1970s onwards, hedging and speculation were further redefined. Banks began to offer swap contracts to clients, such as pension funds or hedge funds, seeking exposure to commodity price movements either to balance equity price risk or to speculate on price changes. The banks soon developed swaps based on commodity price indices and they sought to hedge their price risks arising from these OTC transactions by buying futures contracts on the commodity exchanges. To purchase enough futures contracts to cover the risks from their large-scale swap exposures, banks recognized that they needed to be exempted from speculative position limits. As such, they pushed the CFTC to consider expanding the scope of bona fide hedging exemptions. The CFTC duly obliged, 


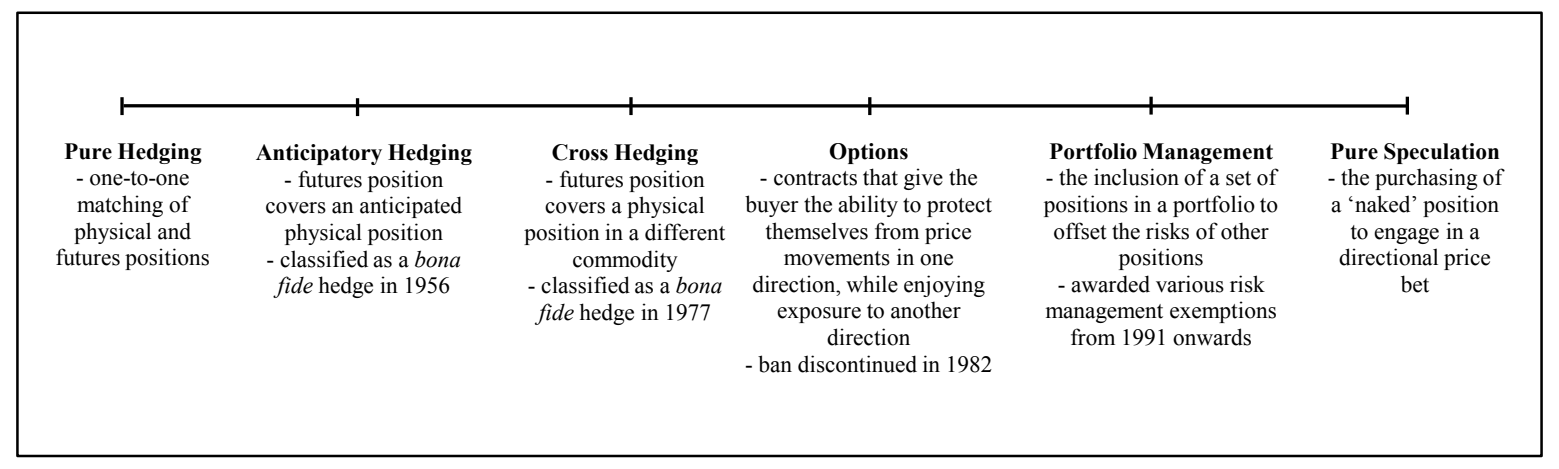

Figure 3: The Hedging-Speculation Continuum

Source: Author's own elaboration

releasing a statement in 1987 that exemptions were not just to be limited to those futures market positions that offset risks arising from cash market positions, but also 'all balance sheet and other trading strategies that are risk reducing' (as cited in US Senate 2009: 107). Accordingly, hedging financial exposures was reclassified as a legitimate risk reducing activity, and from 1991 onward a whole series of banks, beginning with Goldman Sachs, were granted position limit exemptions by the CFTC through "no action' letters so that these entities could hedge their exposures incurred through their commodity index swap activities (Clapp and Helleiner 2012).

The incremental changes in the interpretation of pre-existing rules cumulated into a landmark shift at the turn of the twenty-first century when the 2000 Commodity Futures Modernization Act was passed. This Act explicitly prevented the CFTC from regulating OTC derivatives trading between putatively sophisticated market participants such as banks, pension funds, and large commercial firms (Markham 2014). In so doing, the Act affirmed the principle of self-regulation in the most rapidly developing part of the derivatives sector. The broadening of hedging exemptions and the consolidation of selfregulation enabled investors to flood into agricultural derivatives markets, via CIFs, later in the decade to hedge against inflation and to offset their exposures to equities amid soaring commodity prices and falling stock market prices (Clapp and Helleiner 2012).

Remarkably, in the years leading up to the 2007-08 food crisis, there was little in the way of sustained opposition posed by farm organizations to the changes made to derivatives regulations. True, some outrider organizations representing small-scale and medium-size producers, such as the National Farmers Union, periodically expressed disquiet at the direction of regulatory developments. However, from the 1970s to 1990s interests at the interface of farming and finance were cohesive enough for Roberta 
Romano (1997: 285) to identify a 'tripartite coalition of farm groups, futures exchanges and banks' in the area of derivatives regulation. Farm groups' involvement in this alliance is partly attributable to the fact that by the end of the twentieth century a large portion of US agricultural producers had become wholly incorporated into financialized networks of private risk management. Indeed, in a national survey of farmers in 1977, it was found that only 2 percent hedged using futures markets; three decades later, in 1996, this figure rose to as much as 25 percent (CFTC 1977; GAO 1999: 28). As derivatives markets had thereby become internalized in many farmers' day-to-day operations, a large portion of farmers became less inclined to see the derivatives market as an external force used by entities, such as agricultural commodity traders, whose interests might be inimical to their own (Romano 1997).

Notwithstanding farm groups' general assent to the rule-interpretations underlying the financialized food regime, the broadening of hedging exemptions and the consolidation of self-regulation in derivatives markets has apparently had huge ramifications. To be sure, according to a significant body of research, the high and volatile food prices in 2007-08 and then in 2010-11 were exacerbated by the influx of CIFs facilitated by the extant regulatory framework (e.g. Ghosh 2010; Ederer et al., 2016). Although some scholars have rejected this view (e.g. Irwin et al. 2009; Irwin and Saunders 2010), as this section shows, there has been a broad long-term concordance between financialization and market instability. Furthermore, irrespective of the scholarly debates, grain market instability had a jolting impact on some farm groups' perspectives on the relations between their interests and the interests of the most powerful actors in derivatives markets. The remainder of the paper examines this impact. Specifically, the next section analyzes the distributional effects of grain price instability within the US agri-food sector; and the final section explores how these distributional effects informed different agricultural groups' advocacy efforts after the promulgation of the Dodd-Frank Act.

\section{THE DISTRIBUTIONAL DYNAMICS OF FOOD CRISIS}

In the food crisis of 2007-08, volatility had reached heights that had not been seen since the demise of the state-managerial food regime in the 1970s. As Clapp and Helleiner (2012) point out, this price tumult had significant distributional effects within the US agri-food sector. During the upsurge in volatility, farmers who hedged using futures had to pay increased margin fees in order to keep their futures positions open. Moreover, some grain elevators were not able to afford the increased costs entailed in offsetting their cash commitments to buy grain in advance from farmers. At the height of the crisis, they therefore stopped offering farmers forward contracts. Clapp and Helleiner (2012) also observe that these problems were exacerbated by the fact that, in some grain markets, futures prices and cash prices were not converging at the point of contract expiration, making it harder for farmers to plan production for the future. 
By drawing on income data that has been largely neglected by the literature on the financialization of food, this section builds on Clapp and Helleiner's insights, along with the work of other studies, in three main ways. First, whereas Clapp and Helleiner (2012) chiefly examine the distributional consequences of instability for grain farmers broadly conceived, this section brings animal agriculture into the analysis and offers a disaggregate appraisal of distributional outcomes for farmers across space, commodity specialization and scale. Second, provisionary remarks are also offered in regard to how these dynamics refract along lines of race and gender in rural America. Third, this section examines the income data of the major agricultural commodity traders, and in so doing contributes to existing analysis of the relationship between price instability and the trading houses' earnings (e.g. Baines 2014; Murphy et al. 2012; Salerno 2016).

\subsection{The impacts of instability for farmers by region, and for agricultural commodity traders}

One can justifiably expect that the impacts of price instability will be uneven across space in rural America because one of the key features of the agricultural landscape of the United States is the functional differentiation of the Midwest, where grain production predominates, from the Southern Seaboard, where livestock production predominates (Hart and Mayda 1998). Indeed, the Midwest is home to the two top corn and soybean producing states (Iowa and Illinois) and the two top wheat producing states (Kansas and North Dakota). And the Southern Seaboard - the wide regional arc that extends along the southern and south-eastern coastline of the United States - is home to the largest beef producing state (Texas), the three top poultry producing states (Georgia, Arkansas and Alabama) and the heartland of industrialized hog production (North Carolina). In an initial attempt to disaggregate the distributional consequences of agricultural price instability, Table 1 shows the results of regressing grain price volatility and grain price levels against the relative farm incomes in these state-based groupings. It also offers the results of regressing such price data against the relative earnings of the three largest agricultural commodity traders in the world: Archer Daniels Midland, Bunge and Cargill. According to some estimates, these three companies, together with the highly secretive Louis Dreyfus, account for between 75 percent and 90 percent of the global grain trade (Lawrence 2011).

The relative income of the agricultural commodity traders is calculated through drawing on a method developed by Jonathan Nitzan and Shimshon Bichler (2009) in which the average net income of a given group of firms is divided by the average net income of the top 500 firms listed in the United States, ranked by earnings. The relative income of farmers is calculated by dividing farmers' average nominal income by the average nominal income of nonfarm workers for each quarter. The grain price data are deflated by the producer price index for all commodities. The table chiefly examines the period between the years 2000 and 2015, as the year 2000 is the earliest point in which data on the quarterly net income of all three commodity traders are available. While 
Accumulating through Food Crisis?

\begin{tabular}{|c|c|c|c|}
\hline & $N$ & $\begin{array}{c}\text { Relative Grain } \\
\text { Futures Prices } \\
\text { Standardized Beta } \\
\text { Coefficient }\end{array}$ & $\begin{array}{l}\text { Volatility of Grain } \\
\text { Futures Prices } \\
\text { Standardized Beta } \\
\text { Coefficient }\end{array}$ \\
\hline $\begin{array}{l}\text { Farmer relative in- } \\
\text { come (Midwest) } \\
2000-2015\end{array}$ & 62 & $\begin{array}{c}0.818^{* *} \\
(0.001)\end{array}$ & $\begin{array}{l}-0.165 \\
(0.001)\end{array}$ \\
\hline $\begin{array}{l}\text { Farmer relative in- } \\
\text { come (Southern Sea- } \\
\text { board) 2000-2015 }\end{array}$ & 62 & $\begin{array}{l}-0.379^{* *} \\
(0.001)\end{array}$ & $\begin{array}{l}-0.365^{* *} \\
(0.000)\end{array}$ \\
\hline $\begin{array}{l}\text { Agricultural commod- } \\
\text { ity traders relative } \\
\text { profit } 2000-2015\end{array}$ & 62 & $\begin{array}{c}0.163 \\
(0.071)\end{array}$ & $\begin{array}{l}0.323^{*} \\
(0.068)\end{array}$ \\
\hline $\begin{array}{l}\text { Cargill relative profit } \\
1951-2015\end{array}$ & 65 & $\begin{array}{l}-0.008 \\
(0.001)\end{array}$ & $\begin{array}{c}0.737 * * \\
(0.011)\end{array}$ \\
\hline
\end{tabular}

Table 1: Multilinear Regression Analysis of Agricultural Income and Grain Futures Price Dynamics

** and $*$ denote significance at $99 \%(p \geq .01)$, and $95 \%(p>.05)$ levels, respectively. Standard errors in parentheses.

Source: Farm proprietor and non-farm worker income data from Bureau of Economic of Analysis through Global Insight. Archer Daniels Midland, Bunge and Compustat 500 net income data from Compustat through WRDS. Cargill quarterly net income data from Factiva database and Cargill (2016). Cargill annual net income data from Broehl (1992; 1998; and 2008), Kneen (1995), and Cargill (2016).

Note: For the Midwestern farmer, Southern seaboard farmer and agricultural commodity trader datasets relative grain futures prices are computed by deflating the daily Commodity Research Bureau Grain Index by the interpolated monthly Producer Price Index (all commodities - non-seasonally adjusted). Farm net income data comprise only on-farm income and are restricted to sole proprietorships; they do not include off-farm income and the earnings of corporate farms. Price level data calculated as the average daily price level for each quarter. Price volatility data computed as the standard deviation of the daily changes in relative grain futures prices in each quarter. For the Cargill dataset, price level data are calculated as the average monthly price level for each year; and price volatility data computed as the standard deviation of the monthly changes in relative grain prices in each quarter. Colinearity checked and confirmed absent for regressions covering 2000-2015 and 1951-2015 periods with variance inflation factors of 1.432 and 1.020 respectively.

Louis Dreyfus is omitted from the analysis because data on its net income are only obtainable for the years after 2011, separate regression results for the long-term profit 
dynamics of Cargill are presented because we have earnings data for this firm going all the way back to the $1950 \mathrm{~s}$. The data show a statistically significant positive correlation between the levels of relative grain prices and the relative income of farmers in the Midwest, and no correlation of statistical significance between the volatility of relative grain prices and the relative income of farmers in this region. In contrast, the data reveal statistically significant negative correlations between relative grain price levels and relative grain price volatility, on the one hand, and the relative income of farmers in the Southern Seaboard, on the other. Furthermore, the data show a statistically significant positive correlation between price volatility and the relative earnings of the three largest commodity traders. This positive correlation is especially pronounced in the case of the long-term profit dynamics of Cargill from the 1950s onwards.

The commodity traders tend to thrive during periods of volatility due to their unsurpassed reach into global trade flows, their proprietary control over private grain storage data, and their often privileged access to policymakers and supply chain participants. Indeed, as they are privy to multifarious streams of commercially-relevant information they have a clear lead in the 'price discovery' process. And during periods of price turbulence, this lead tends to widen as the agricultural commodity traders can take advantage of the disorientation of other market participants. The growing informational asymmetries afford the commodity traders increased market power as they can navigate larger profit opportunities through arbitrage, speculation or the ramped up provision of private risk-management services to less informed actors. In fact, in 2007, when agricultural price volatility increased sharply, Cargill's risk management and financial division accounted for an astounding 34 percent of the company's net income (Bloomberg 2014). As such, the agricultural commodity traders may be among the main beneficiaries of the financialization of food and the coeval decline of public grain stocks (Murphy et al. 2012; Salerno 2016).

Turning to agricultural producers, it is understandable that Midwestern farmers benefit from high prices given the fact that, ceteris paribus, higher grain prices will lead to wider profit margins for grain farmers. But there is not a positive correlation between Midwestern farmers' income and grain price volatility for reasons that have been wellestablished by Clapp and Helleiner (2012), and that were recounted at the beginning of this section. However, what the existing literature tends to miss is that livestock producers are generally hit the hardest by high and volatile grain prices. For while grain price changes will move in line with the prices received for the output of many farmers in the Midwest, they will broadly move in sync with the input costs borne by the many livestock producers concentrated in the Southern Seaboard. To be sure, feed grain comprises 60-70 percent of livestock production costs in the United States, and thus high grain prices are associated with crimped margins in regions where animal agriculture predominates (Becker 2008). In addition, unlike grain farmers, livestock farmers cannot withhold their product using on-farm storage facilities in the hope of more favorable price conditions in the future. The marketing window for live animals is simply too short and the handling costs are too high. Livestock farmers thus appear particularly vulnerable to price fluctuations. Moreover, it is worth noting that the distributional 
patterns outlined here are imbricated in highly racialized inequalities. According to the latest census data, 90 percent of black farmers operate in just six southern states, and Hispanic farmers are similarly concentrated in the South (USDA 2014a). Additionally, in terms of commodity-specialization, more than two-thirds of Native American farms are engaged in livestock production, compared to just half of all farms (USDA 2014b). By way of contrast, the farming population in the grain growing regions of the Midwest are overwhelmingly of northern European origin. Given these demographics, farmers of colour are more likely to be negatively impacted by high and volatile grain prices.

\subsection{A deeper look: the impacts of instability for farmers across commodity specialization and scale}

Figure 4 further disaggregates the picture for agricultural producers, as it presents annual inflation-adjusted data on farmer income patterns according to commodityspecialization. It appears to show that among grain producers, wheat growers have the most volatile earnings; while among livestock producers, cattle ranchers have the most unstable income. These varying levels of income volatility are partly attributable to the specificities of different forms of agriculture. Ranchers are in a particularly precarious position because cattle have the longest biological cycle of all farmed animals in the United States. The gestation period for calves is nine months, and then cows can live for up to one and a half years before they are killed. In contrast, it takes just 13 weeks to bring chickens from zygote-state to slaughter weight, and just 45 weeks for hogs. As a result of the longer biological cycle of cows, it takes a longer time for cattle producers to adjust population levels to new feed grain price conditions, and they are thus particularly harmed by grain price volatility (MacDonald 2008; McBride and Matthews 2011). In regard to crop producers, the fact that wheat growers appear to have more volatile earnings than corn and soybean producers is also in part attributable to the irreducible biophysical specificities of different forms of farming. Most importantly, in the Corn Belt growing conditions are highly versatile. Corn farmers can easily shift production to other feed grains, especially soybeans as they are a key rotation crop. In contrast, in the Wheat Belt, growing conditions are less propitious for crop diversification. Wheat growers are thus less able to switch production in the face of adverse price conditions (Winders 2009).

Figure 5 sheds light on the severity of convergence problems for corn, soybean and wheat markets, while also offering a more granular picture of price volatility and financialization. Specifically, the top chart depicts the speculation ratios for the Chicago Board of Trade's soft red wheat, soybean and corn contracts. The speculation ratio is calculated by dividing the long positions held by commodity index traders by the short positions for the corresponding futures contracts held by market participants with positions in physical markets. Following Shanmugam and Armah (2012), we can use this ratio as a rough measure of the degree to which CIFs exceed the socially useful function of providing liquidity to entities involved in the production and trade of 


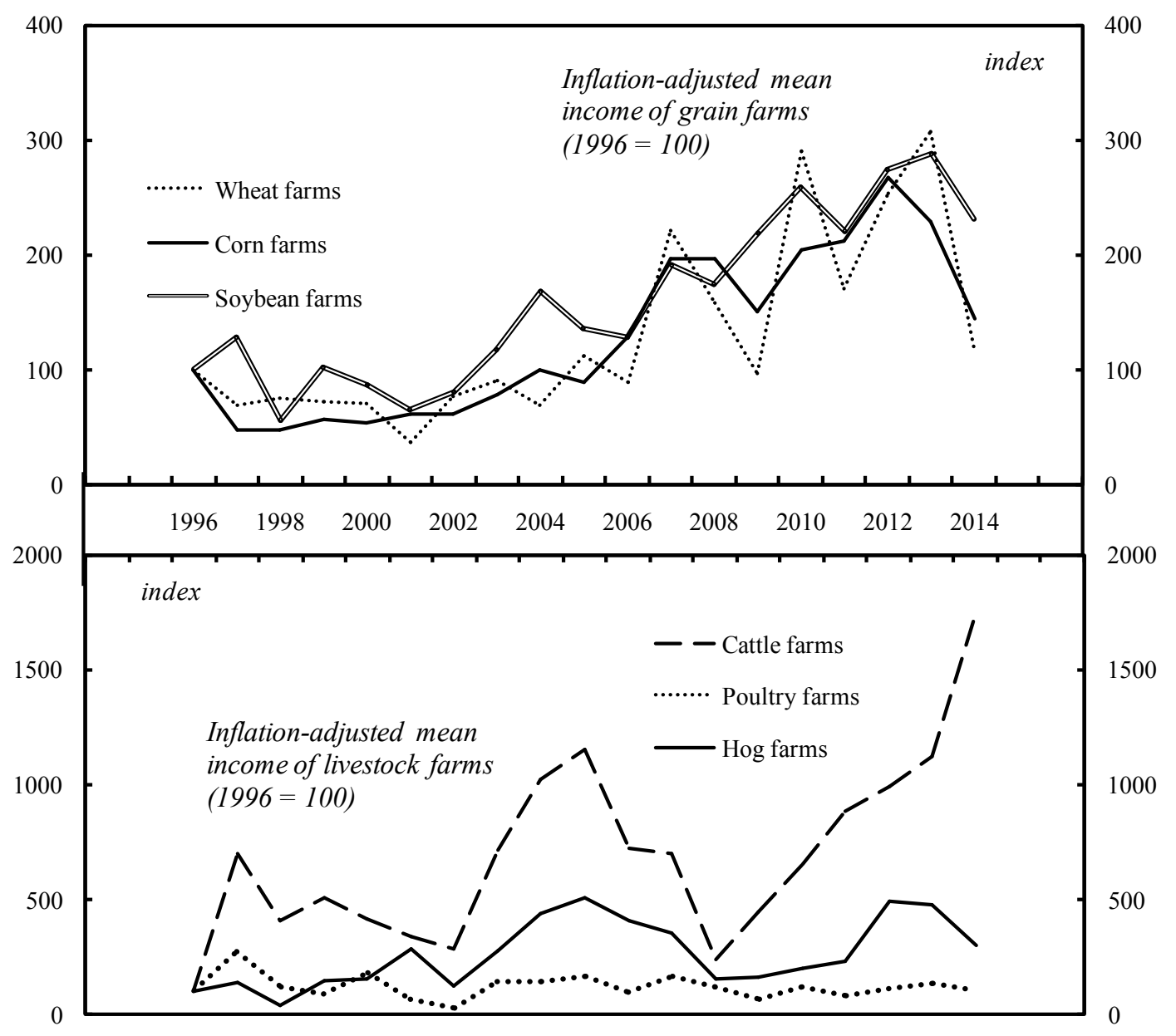

Figure 4: Farm Income by Production Speciality, 1996-2014

Note: Farm income deflated by Commodity Price Index.

Source: Commodity Price Index from Bureau of Economic Analysis through Global Insight. Farm income data from USDA (2016).

physical commodities. The second chart down offers data on the 'basis' of wheat, soybeans and corn. The basis is the cash price minus the futures price for any given agricultural commodity at the point of contract expiration, and thus indicates the extent to which cash markets and futures markets are decoupled. Finally, the bottom two charts of Figure 5 offer a close view of inflation-adjusted price levels and volatility in wheat, soybeans and corn futures in the Chicago Board of Trade. 


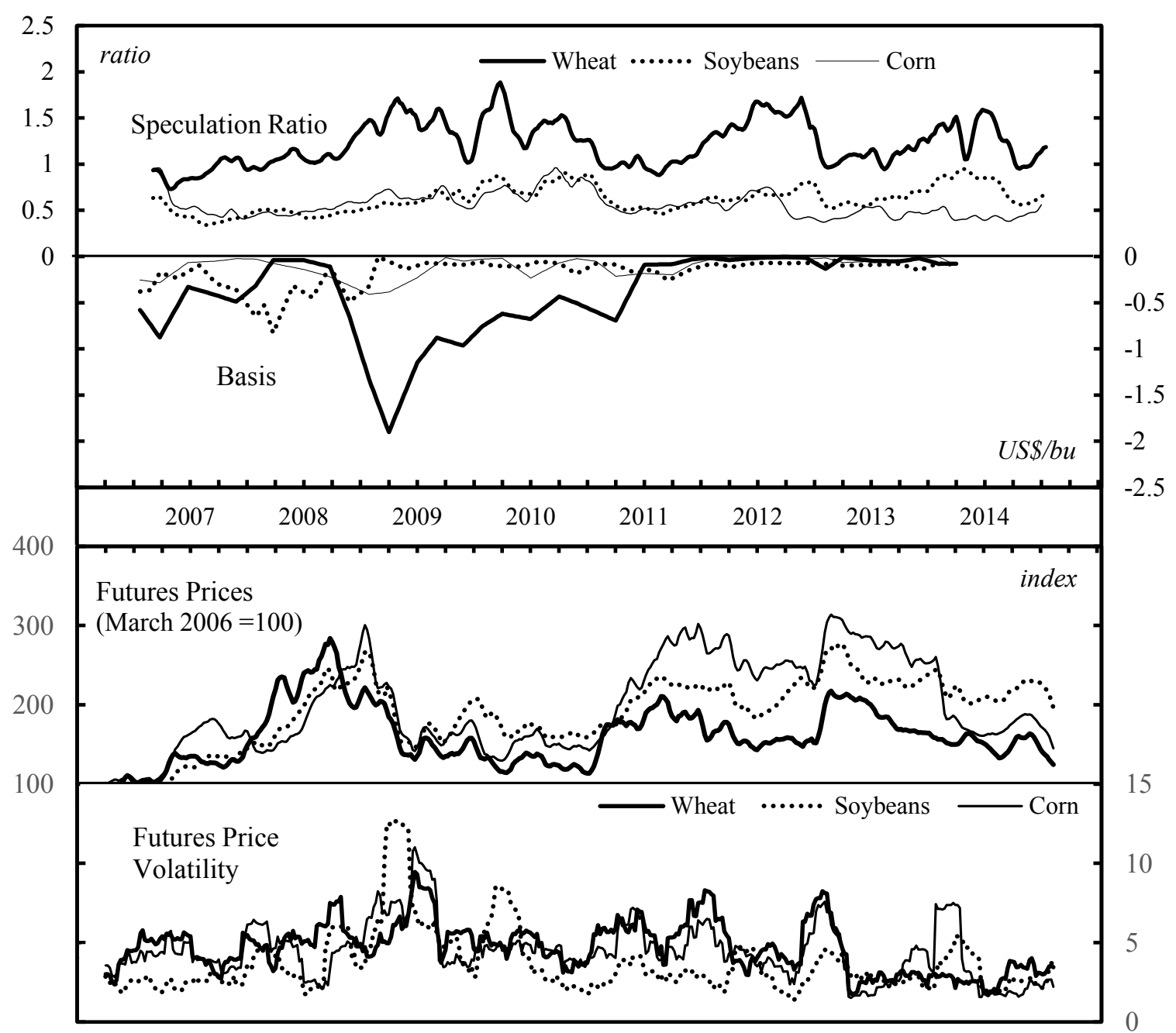

Figure 5: Short-Run Dynamics in Grain Futures Markets, 2006-2015

Note: Basis is calculated by subtracting the futures price from the cash price of a given commodity at its contract expiry date. The speculation ratio is calculated by dividing the long-positions held by commodity index traders by the short-positions for the corresponding futures contracts held by market participants with positions in physical markets. Futures price data pre-adjusted for inflation by Global Financial Data database. The data cover the CBOT's soft red wheat, corn and soybean futures contracts.

Source: Basis data from Hoffman and Aulerich (2013). Data on market positions of commodity index funds, producers and merchants from CFTC (2016a). Futures price data from Global Financial Data database. 
Three major observations can be made in regard to the figure. Firstly, since its peak in 2008-09, futures price volatility has trended downward, albeit in stuttering fashion; and there has been a decline in futures price levels since the end of 2012. Secondly, the wheat market has been beset with the most acute convergence problems with basis bottoming out at -US\$1.90 per bushel towards the end of 2008. In contrast, non-convergence of cash and futures has been relatively mild in corn and soybean markets. Thirdly, of all the grain markets, the wheat market is the most financialized insofar as the speculation ratio for the soft red wheat contract in Chicago climaxed at a multiple of 1.96 of the short-positions of those futures market participants with exposures in physical markets. In contrast, at their respective peaks the speculation ratios of soybean and corn markets reached 1.02 and 0.96 respectively. The disproportionate degree of financialization in the wheat market is a result of the fact that while wheat contracts have a much larger dollar-weighting in commodity indexes such as the S\&P GSCI than that of corn and soybean contracts, wheat output is much smaller than that of US corn output, and marginally smaller than that of soybean output (Mayhew 2012; USDA 2016b, 2016c). These data therefore further confirm that different forms of agriculture have become enveloped within the networks of finance in highly variegated ways.

Table 2 offers the final set of quantitative data for this section. The table presents information on farmer income patterns according to commodity-specialization and size. Large commercial farms are defined as farms with US\$350,000 or more in gross cash receipts from farm operations and government payments, along with nonfamily farms. Small and mid-size family farms are defined as farms with less than US\$350,000 in gross cash receipts and a principal operator whose primary occupation is farming. Interestingly, the table confirms that cattle ranching is the most precarious farming activity. To be sure, cattle growers register by far the lowest average income, the lowest average profit margins, and the highest volatility in profit margins. It also confirms that corn and soybean growers enjoy much steadier profit margins than wheat growers. Finally, the table offers highly significant data on farm income patterns across scale. For every commodity category, large-scale farms have higher and more stable profit margins than small and mid-size farms. Furthermore, the average on-farm net income of largescale commercial farms is US\$354,541. Bearing in mind that the average off-farm net income of US farms is as high as US\$72,665 (Hoppe 2014) and that, according to Saez (2015), the cut-off point for being in the top income percentile in the United States is $\$ 394,000$, we arrive at a stunning finding: the average income of large-scale farms reaches the earnings threshold of the top one percent of US households. As such, largescale farmers are at the very top of the US's income hierarchy. ${ }^{3}$ Asterisks are placed in the table beside other farm group categories that have an average income which exceeds the thresholds required to get into the top decile, ventile (five percent) and percentile of US households in terms of earnings.

The differences in profit margins and earnings stability across scale partly arise from the fact that large farms can manage the privatization of risk that has attended the rise of the financialized food regime more effectively than smaller operators. Indeed, largescale crop producers are more likely to be able to afford to invest significantly in farm 


\begin{tabular}{|c|c|c|c|c|}
\hline & $\begin{array}{r}\text { Average net } \\
\text { farm income } \\
\text { (US\$) } \\
2014\end{array}$ & Population & $\begin{array}{r}\text { Average profit } \\
\text { margin } \\
\text { (percent) } \\
1996-2014 \\
\end{array}$ & $\begin{array}{r}\begin{array}{r}\text { Volatility of } \\
\text { profit margin }\end{array} \\
1996-2014\end{array}$ \\
\hline All US farms & 45,312 & $2,076,273$ & 23.2 & 20.9 \\
\hline Large commercial*** & 354,541 & 219,955 & 24.2 & 19.3 \\
\hline Small and mid-size & 15,981 & 631,718 & 18.7 & 38.1 \\
\hline Wheat - all farms & 45,067 & 25,391 & 26.5 & 53.2 \\
\hline Large commercial** & 157,790 & 6,518 & 28.4 & 50.9 \\
\hline Small and mid-size & 4,939 & 10,343 & 20.8 & 108.2 \\
\hline Corn - all farms* & 86,659 & 117,817 & 27.4 & 26.1 \\
\hline Large commercial** & 224,177 & 40,265 & 27.9 & 26.4 \\
\hline Small and mid-size & 18,273 & 34,878 & 21.7 & 49.3 \\
\hline Soybean-all farms* & 51,641 & 101,614 & 26.0 & 29.9 \\
\hline Large commercial** & 216,260 & 20,020 & 26.1 & 34.7 \\
\hline Small and mid-size & 20,020 & 38,880 & 21.0 & 68.6 \\
\hline Cattle - all farms & 28,565 & 730,756 & 18.8 & 119.0 \\
\hline Large commercial*** & 437,317 & 34,570 & 20.0 & 63.2 \\
\hline Small and mid-size & 15,106 & 238,766 & 17.5 & 646.3 \\
\hline Hogs - all farms $* *$ & 114,167 & 22,948 & 24.4 & 55.8 \\
\hline Large commercial $* * *$ & 334,747 & 7,245 & 25.4 & 56.0 \\
\hline Small and mid-size & 22,896 & 7,197 & 17.9 & 196.4 \\
\hline Poultry - all farms* & 61,434 & 49,623 & 28.6 & 106.0 \\
\hline Large commercial*** & 778,527 & 4,439 & 28.4 & 105.8 \\
\hline Small and mid-size & 31,899 & 24,226 & 23.1 & 473.0 \\
\hline
\end{tabular}

\section{Table 2: Income and Precarity in US Agriculture}

\footnotetext{
*** Top income percentile of US households; ** Top income ventile; * Top income decile
}

Notes: A farm is defined by the USDA as any place from which $\$ 1,000$ or more of agricultural products are normally produced and sold annually. Farms are categorized in the top 1 percent, top 5 percent, and top 10 percent classifications if the sum of average on-farm income and the average off-farm income (US\$72,665 (Hoppe, 2014)) exceed the thresholds computed by Saez (2015). The thresholds for the top income percentile, top 5 percent and top decile are US $\$ 392,000$, US $\$ 165,000$, and US $\$ 116,000$ respectively. Net farm income data for large commercial poultry farmers in 2014 is missing. As such, the value for 2013 is included instead. Volatility of profit margin is calculated as the standard deviation of the annual rate of change of profit margins.

Source: USDA Economic Research Service Agricultural Resource Management Survey database. 
storage facilities. This is very important in the context of the diminution of public grain storage programs, as it means that largescale farmers have greater capacity than small farms to spread sales out over the storage season and thereby avoid the risks that arise from selling everything at one time. It has also been found that largescale producers are more likely to hedge using futures, in part because many small farmers lack the information and technical knowhow to engage in futures market trading. ${ }^{4}$ Furthermore, large-scale farmers are not only better able to reduce risk, they are also better able to speculate profitably. Particularly revealing in this regard are the findings provided by Farm Futures - a magazine that regularly surveys its readership of predominantly highincome farmers. According to one such study, it was found that ' $40 \%$ of those surveyed did some type of speculating with futures or options' (Knorr 2007: 20). Finally, some large farmers combine their acumen in derivatives markets with their storage capacity in physical markets to engage in speculative hoarding: a practice in which grain is kept from the market in the hope of rising prices in the future, while option contracts are held as protection from downside risk (Pleven 2012). Thus, given their greater storage capacity and use of futures markets, large farmers tend to be at an advantage in the context of financialization and the depletion of public grain reserves. ${ }^{5}$ And again, these dynamics refract unevenly along lines of race as well as gender. Indeed, of all farms in the United States, 25 percent have gross earnings in excess of US\$50,000; but only 18 percent of Hispanic farms, 9 percent of Native American farms, and just 6 percent of farms whose principal operator is Black, exceed this annual sum. Similarly, only 10 percent of farms that are principally operated by women surpass this threshold (USDA 2014a). Given these data, it is probable that financialization and associated instability tend to reinforce the multifaceted asymmetries in power and income that exist within rural America.

\section{COALITIONAL POLITICS IN THE DODD-FRANK REFORM PROCESS}

This section analyzes the coalitional dynamics of agricultural groups around commodity derivatives reform. As with the previous section, Clapp and Helleiner's analysis is particularly instructive as they convincingly argue that the agricultural groups that faced losses and acute uncertainty from the price instability of 2007-09 united with interest groups in other sectors affected by market tumult to actively push for wide-ranging curbs on speculation. Following on from these observations, Pagliari and Young (2014) incorporate Clapp and Helleiner's analysis to offer an insightful macroscopic exploration of the plural politics of financial regulation; arguing that the mobilization of agricultural groups countervailed the lobbying efforts of financial firms directly targeted by commodity derivatives regulation. Pagliari and Young contrast these coalitional 
politics to those in other areas such as credit derivatives regulation where no such countervailing mobilization was evident. In fact, in this area, major commercial entities formed the Coalition for Derivatives End-Users (CDEU) to amplify the influence of Wall Street banks (Pagliari and Young 2014).

Notwithstanding the strengths of these analyses, due to the times at which these articles were written they principally focus on agricultural interest group involvement in the legislative battles that culminated in the passing of the 2010 Dodd-Frank Act. Accordingly, this section extends the existing literature by investigating agricultural advocacy efforts after the passing of the Act. It does so, first, by examining the evolving alliances at the interface of agriculture and finance during the rulemaking period; and second, by exploring the conflict between these alliances around the timing and scope of new position limits.

\subsection{Alliance formation at the interface of agriculture and finance}

It has been well-established by Clapp and Helleiner (2012) that the market dislocation of 2007-09 led to the sudden re-politicization of commodity derivatives markets. In the domain of agricultural derivatives, the tacit alliance between those financial and corporate interests that actively pushed for self-regulation, and those farming interests that passively acceded to it, was in abeyance and a new, more conflictual, configuration of interests emerged. This configuration is displayed in Figure 6 as it maps out the nexus of agricultural and financial groups that lobbied over commodity derivatives regulation at the beginning of the rulemaking process. The figure shows that the agricultural and financial groups coalesced into two more or less distinct constellations. Using the terms of Ziegler and Woolley (2016), these constellations can be described as the 'stability alliance' and the 'self-regulation alliance'.

The stability alliance largely comprises the groups that have been most harmed by price instability and have been least able to benefit from the privatization of risk that emerged with the financialized food regime. This alliance has therefore called for wideranging reforms to derivatives markets. Indeed, of the agricultural advocacy organizations within the pro-reform Commodity Markets Oversight Coalition (CMOC), one-half lobby on behalf of cattle producers. The remaining agricultural organizations of the CMOC represent feed interests, family farmers, and ethno-cultural farmer groups which stand for the interests of Hispanic and African American agricultural producers alike. Moreover, of the three general farm organizations in CMOC, the National Farmers Union - the historic mouthpiece for small and middle-income farm interests, particularly in the wheat belt - is by far the largest. In contrast, the self-regulation alliance is composed of groups that have largely prospered in the financialized food regime and that have accordingly shared a preference for light-touch government treatment and the resolution of problems principally on the basis of regulatory self-rule. It includes two key lobbying organizations: the International Swaps and Derivatives Association (ISDA) and the Commodity Markets Council (CMC). The former primarily represents 

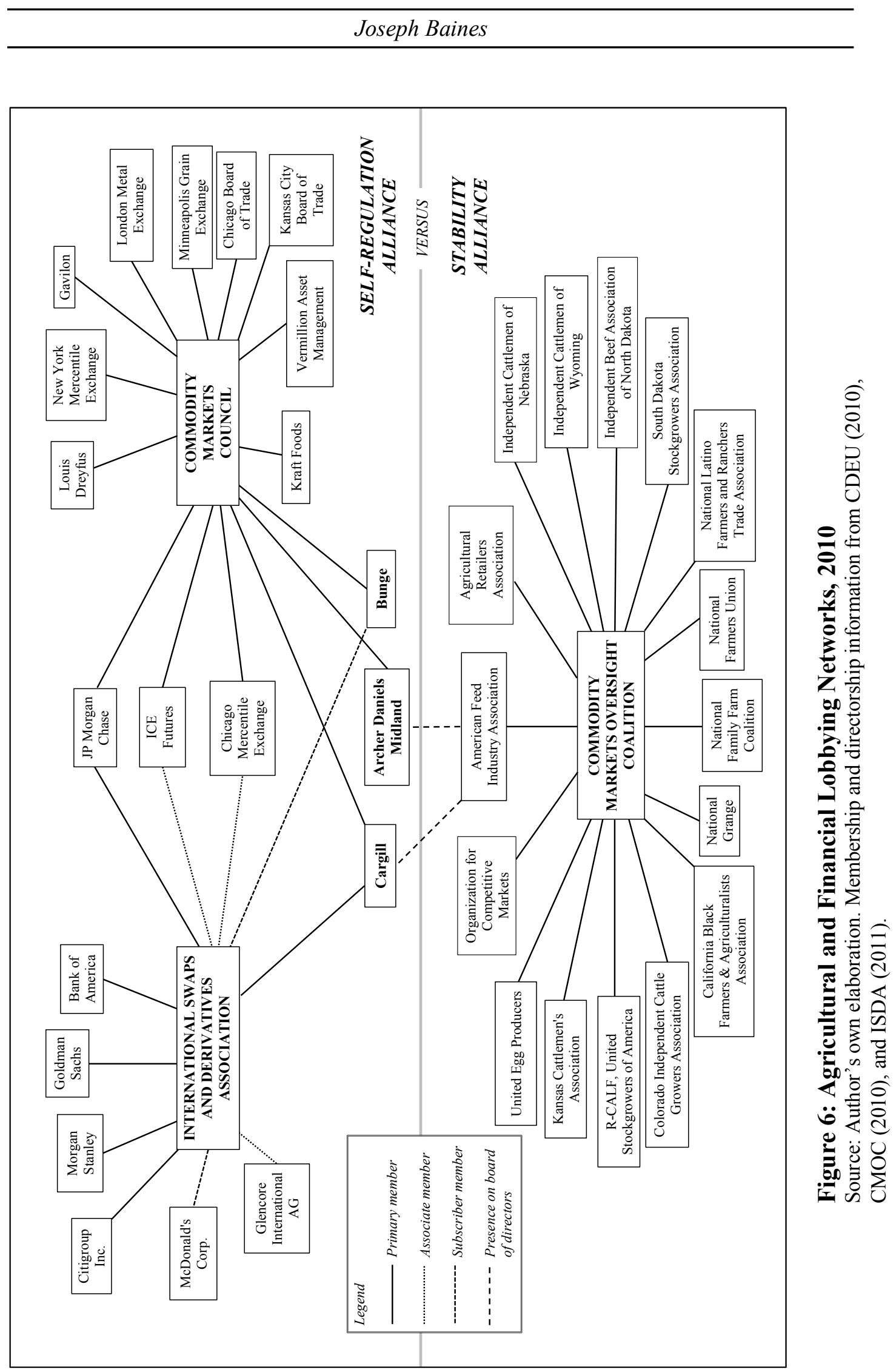
the Wall Street banks that dominate swap dealing activities, while the latter principally represents commodity exchanges and the major commodity traders. Due to space constraints, the commercial firms operating outside of the agri-food sector are not included in the figure.

In the years that followed the global financial crisis, dynamics within agricultural commodity markets changed markedly. Commodity exchanges worked in consultation with commodity traders and farm groups to make technical alterations to corn, wheat and soybean contracts to combat convergence issues, and as indicated in Figure 5 these alterations successfully brought futures and cash markets into alignment (Hoffman and Aulerich 2013). Moreover, volatility in agricultural prices also declined around the same period, and the incomes of the groups that were worst hit by the 2007-09 spike in price instability - cattle producers and wheat growers - recovered significantly in the five years that followed (see Figure 4). In this context, arguments in favor of far-reaching derivatives reform appeared to no longer resonate so broadly. As Figure 7 indicates, these changes had a significant impact on coalitional dynamics. The diagram presents the nexus of agricultural and financial groups lobbying around commodity derivatives reform in 2016. The agricultural constellation within CMOC clearly shrank in size: in 2010, 16 agricultural organizations were members of CMOC; but by 2016 there were only seven members. And while the stability alliance has waned, the self-regulation alliance has expanded. Most noteworthy in this regard is the enrolment of the leading commodity-specific interest groups in US crop agriculture, along with the standardbearer of large-scale farm interests - the Farm Bureau - into the CDEU. The participation of non-financial groups in obstructing reform has been thoroughly examined by Pagliari and Young (2014) in the field of credit derivatives regulation. But what has been missed so far is that agricultural interests have been among those that supported attempts to thwart swift regulatory changes in commodity derivatives reform. Given the nexus of interests connecting the CDEU to the CMC and ISDA, it seems that the 'tripartite coalition of farm groups, futures exchanges and banks' identified by Romano in the 1990s reconstituted itself during the Dodd-Frank rulemaking process.

\subsection{Rule ambiguity: the contested boundary between hedging and speculation}

In line with the power-distributional approach, the self-regulation alliance and stability alliance did not emerge simply as a result of the uneven consequences of the financialized food regime. Rather, they took form as movements embodying different interpretations of the ambiguous rules governing derivatives markets. Of particular significance here are the definitional conflicts surrounding the regulatory delineation of hedging and speculation, as this delineation effectively determines the border between those entities that are subject to speculative position limits and those which are exempted from them. ${ }^{6}$ 


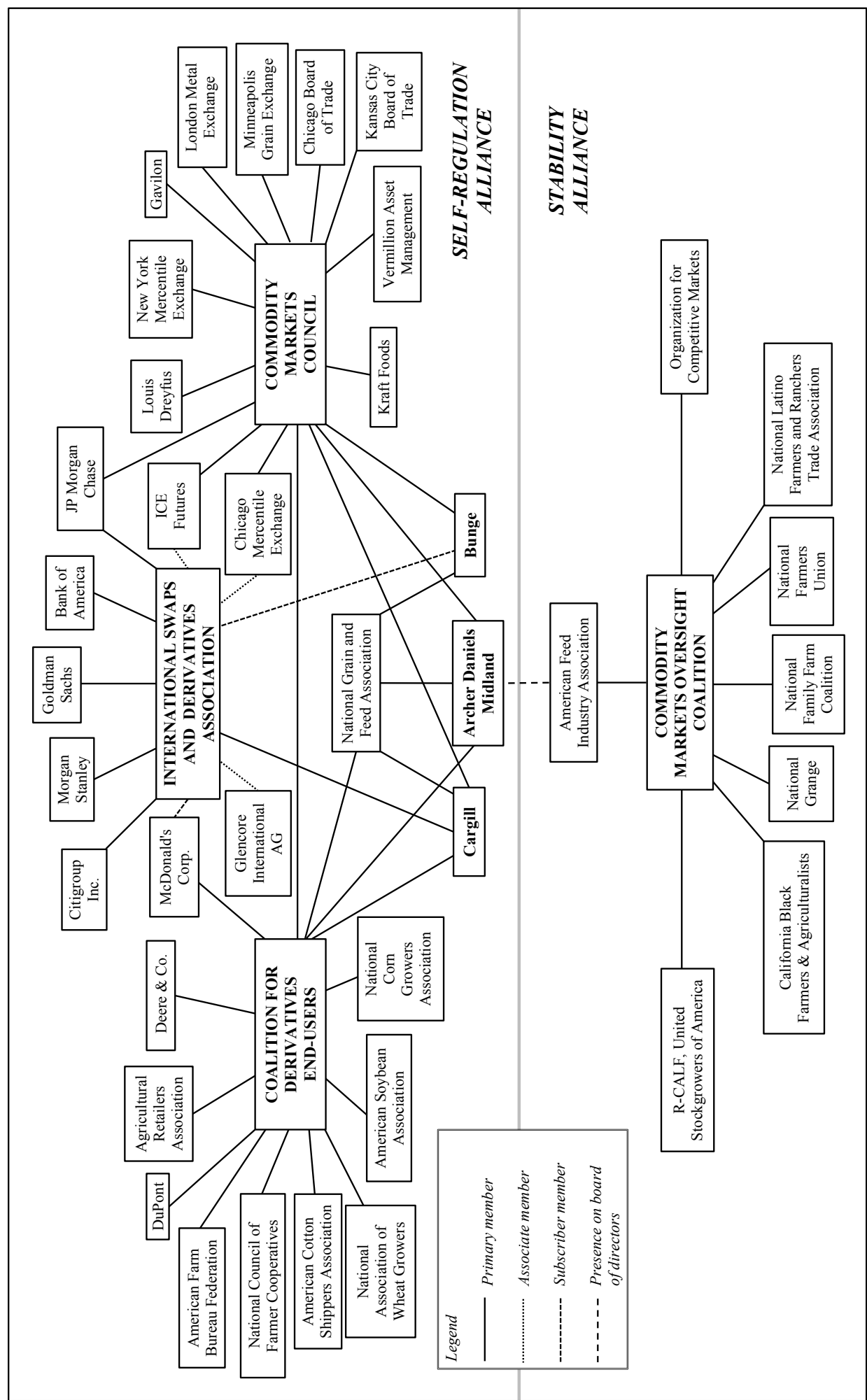

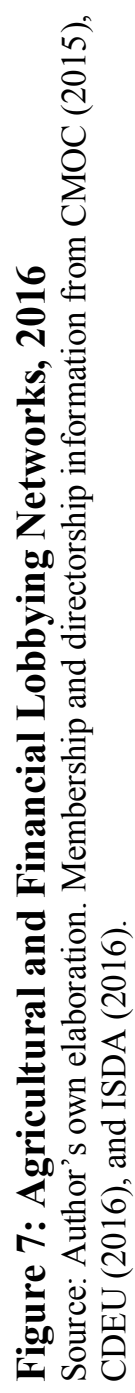


As the first section argued, one key driver of the financialization of grain markets was the broadening of US regulators' interpretation of legitimate hedging activity from the 1950s onwards. But, in response to the turmoil of 2007-09, some farm organizations called for a narrowing of hedging exemptions. For example, the National Association of Wheat Growers was unequivocally against the 'swaps loophole' that had been granted to CIFs in the lead-up to the price instability of 2007-09, stating bluntly that '[d]iversifying risk in an investment portfolio should not pass the test for a hedge exemption; these exemptions should be reserved for parties who commercially produce, own or use wheat' (USW 2008). Although the National Association of Wheat Growers eventually joined the self-regulation alliance, other farm groups have been more steadfast in their opposition to unfettered index fund activity. To be sure, the National Farmers Union - a core constituent of the stability alliance - has continued to urge the Senate Committee on Agriculture, Nutrition and Forestry 'to direct CFTC to limit or end index fund commodity speculation' (NFU 2013).

Moreover, some farm organizations have gone one step further by attributing speculative motives to commercial firms themselves. For example, the RanchersCattlemen Action Legal Fund - another mainstay of the stability alliance - accused the major beef packers, including Cargill itself, of engaging in untrammelled speculation: 'cattle producers, some of whom continue to rely on futures markets to offset price risk, are vulnerable to any market distortions caused by beef packers that may not only participate in the futures market as physical hedgers, but as significant speculators as well.' (R-CALF 2011, my emphasis). At the beginning of the rulemaking process, CFTC staffers similarly suspected that self-described commercial entities may be engaging in speculative activity. Indeed, a report authored by a former General Counsel and a former Chief of Staff at the CFTC confirms that staffers within the agency have been 'skeptical of the price risk management utility of many common commercial risk management practices, particularly those used by commodity merchandisers [i.e. the commodity traders]' (Arbit et al. 2013). In order to close loopholes that might allow excessive speculation to take place under the guise of hedging, the CFTC proposed narrowing the exemptions for two longstanding risk management practices: cross-hedging and anticipatory hedging. As discussed in the first section, these two practices - like many other forms of risk management - can combine both speculative and risk-reducing motives, and thus defy clear classification.

The slated restrictions were actively opposed by a number of agricultural groups, not least the agricultural commodity traders themselves because of the key role that both cross-hedging and anticipatory hedging play in these firms' operations. Their concern was clearly articulated by a representative of Cargill's risk management division during a House Committee on Agriculture hearing in 2011:

While Congress made clear in its bona fide hedge definition that companies engaged in the physical trade should receive an exemption for anticipatory merchandising positions, the CFTC through its proposed rules would deny companies the exemption and would recharacterize them as speculative. This is not only inconsistent with the 
law, but has the potential to have calamitous effects in the cash commodity markets. (Cargill 2011)

The self-regulation alliance has been bolstered by the fact that some farm groups have echoed these complaints. For example, early on in the rulemaking process the National Corn Growers Association stated that the CFTC's proposed 'bona fide hedge exemption provisions are overly restrictive and unnecessarily burdensome' (NCGA and NGSA 2011a). Furthermore, the National Corn Growers Association has pushed for the CFTC to be sent back to the drawing board and be given 'more time to craft rules' (NCGA and NGSA 2011b). Interestingly, this position contrasts sharply with that of the National Farmers Union (2011), which has called for '[s]wift action to curb or ban excessive speculation'. The National Corn Growers Association's qualms about swift reform stem in part from concerns regarding the possible regulatory costs imposed by reduced exemptive relief from position limits. This perspective was well articulated in a letter to the CFTC in 2014 authored by the Farm Bureau: Changes in the definition [of hedging] itself and changes in the way it is interpreted by the CFTC would have far-reaching consequences for bona fide hedgers in agriculture... such action likely would lead to a markedly reduced ability for grain elevators, feed manufacturers, processors and other businesses to hedge their physical commodity risk and force grain and oilseed purchasers to reduce bids to farmers and limit the risk management programs that can be offered to farmers and ranchers. (AFBF 2014)

One should by no means assume that the National Corn Growers Association and the Farm Bureau provide an unmediated expression of the interests of farmers on the ground. Nonetheless, their stated views do indicate that some farm groups have become highly integrated in the advocacy networks that support the rule-interpretations upon which the financialized food regime is based. With a direct stake in the privatized modalities of risk management that have accompanied financialization, some of the more privileged segments of US agriculture appear to have little appetite for deviating from the policy positions expressed by powerful trading and financial interests

With this in mind, Figure 8 offers us more insights in regard to the direction in which regulatory debates have moved. The chart presents data on the levels of advocacy activity by $\mathrm{CMOC}, \mathrm{CDEU}$ and $\mathrm{CMC}$ as measured by the relative proportion of comments submitted to the CFTC on its position limits ruling by these three organizations and by agricultural groups therein. One can see that at the very beginning of the rulemaking process, the submission of comment letters to the CFTC was fairly evenly balanced between CMOC, on the one hand, and the CDEU and the CMC, on the other. Then, for all but one year between 2011 and 2014, CDEU and its agricultural member organizations were the most active advocates, only then to be superseded by CMC. Given these changes it appears that as the regulatory process has unfolded, the debates surrounding reform have shifted from groups representing small-scale farmers to groups representing large-scale farmers, and then from farmers in general to the corporate and financial entities at the apex of the financialized food regime. 
Accumulating through Food Crisis?

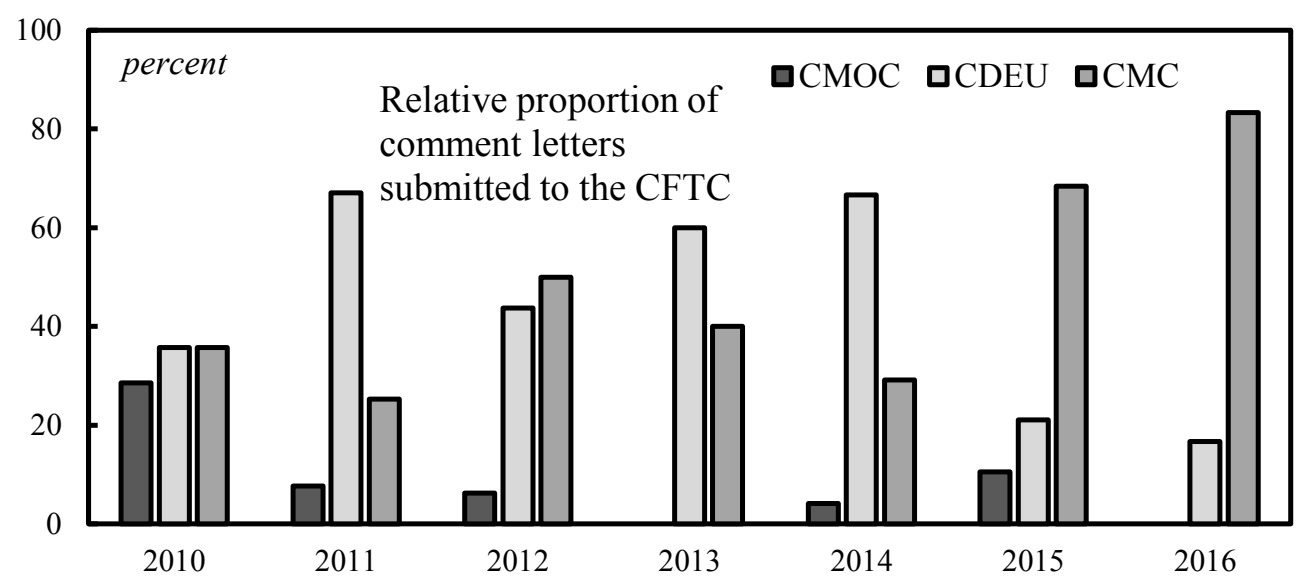

Figure 8: Advocacy Efforts during Derivatives Reform Debates

Note: Relative proportion of comment letters submitted to the CFTC is measured by dividing the number of submissions from the $\mathrm{CMOC}, \mathrm{CDEU}$ and $\mathrm{CMC}$ and their respective agricultural members by the total number of submissions from these groups.

Source: Comment submissions information from CFTC (2016b).

In further evidence that regulatory debates have become more removed from grassroots agricultural organizations, in June 2014 the CFTC held a roundtable with commodity exchanges and commodity traders to address their concerns regarding the bona fide hedging exemption. The danger of such meetings is that, as discussions around the appropriate regulatory delineation of hedging and speculation get ever more technical, regulators become increasingly beholden to the intricate risk management knowledge of those entities that it might otherwise regulate. By extension, in these complex debates, the stability alliance may not have the informational capacity to determine the interests of its own constituents, let alone represent them effectively. The possible outcome is that, in spite of the best efforts of some individuals in the CFTC, the regulatory landscape is warped in favor of incumbent leaders in derivatives markets at the expense of lessinformed and less-resourced actors. After a period of acrimony between the CFTC and the largest corporate users of commodity derivatives, this cognitive capture may be in progress. In May 2016, the CFTC succumbed to at least some of the arguments of the self-regulation alliance by loosening the hedging definition and by allowing commodity exchanges greater discretion in granting position limit exemptions (Blosfield and Osipovich 2016). Thus, as the rulemaking process becomes ever more complicated and as volatility has temporarily waned, the dynamics of commodity derivatives reform appear to be shifting decisively in the favor of the self-regulation alliance. 
Bringing these points together, it becomes clear that the advocacy efforts of farm groups in favor of the Dodd-Frank Act were more uneven than readers of Clapp and Helleiner (2012) and Pagliari and Young (2014) might have thought. And these advocacy efforts have been less sustained than supporters of far-reaching reform might have hoped. To be sure, at the time of writing it was entirely appropriate for Clapp and Helleiner (2012: 201) to tentatively venture that 'the efforts of US agricultural groups to defend their interests may end up generating an outcome - less volatile global agricultural prices which strengthens the food security of the world's poor'. But the subsequent work of these two authors in broader fields of investigation, along with the detailed analysis here, attests that a more pessimistic prognosis may now be in order (see Clapp 2014; Helleiner 2014). As this section has shown, since the rulemaking process began, both large-scale crop growers and agricultural commodity traders have stood in the way of swift and farreaching regulatory measures designed to curb price instability. Moreover, as the previous section showed, large-scale grain producers have generally benefited from high grain prices, and the commodity traders have tended to prosper amid grain price volatility. Conversely, it has been well-documented that high and volatile prices have grave impacts on those food insecure populations around the world that, after decades of growing import dependency and declining public grain reserves, are exposed to the vicissitudes of world markets (Patel and McMichael 2009; Scott-Villiers et al. 2016).

By way of closing the circle of this analysis, Figure 9 helps us situate the conflict between the stability alliance and the self-regulation alliance in an international context. Taking its cue from Lagi et al. (2011) who link the outbreak of social unrest to changing food prices, the figure connects the outbreak of social unrest to relative income and profitability within the US agri-food sector. More specifically, the solid line tracks the average net income to sales ratio of the agricultural commodity traders relative to the average net income to sales ratio of the top 500 largest corporations listed in the United States; the duplex line traces the relative income of Midwestern farmers; and finally, the dotted lines rising from the chart's $\mathrm{x}$-axis indicate the beginning dates of the major 'food riots' and revolts of the early twenty-first century. ${ }^{7}$ The chart shows that surges in the relative income of Midwestern farmers and the relative profitability of the trading houses have been coeval with bouts of social upheaval abroad. Indeed, it is clear that Midwestern farmers - with the possible exception of marginal farmers, especially in the Wheat Belt - generally benefited from the agricultural price spikes of 2007-08 and 2010-11. And it is also clear that agricultural commodity traders accumulated rapidly during these crises. If the financialized food regime persists in its current form, it is highly likely that these two groups will once again be among the key winners of future rounds of high and volatile prices in grain markets. However, the consequences of ongoing financialization for societies that are existentially vulnerable to sudden food price rises might be dire. 


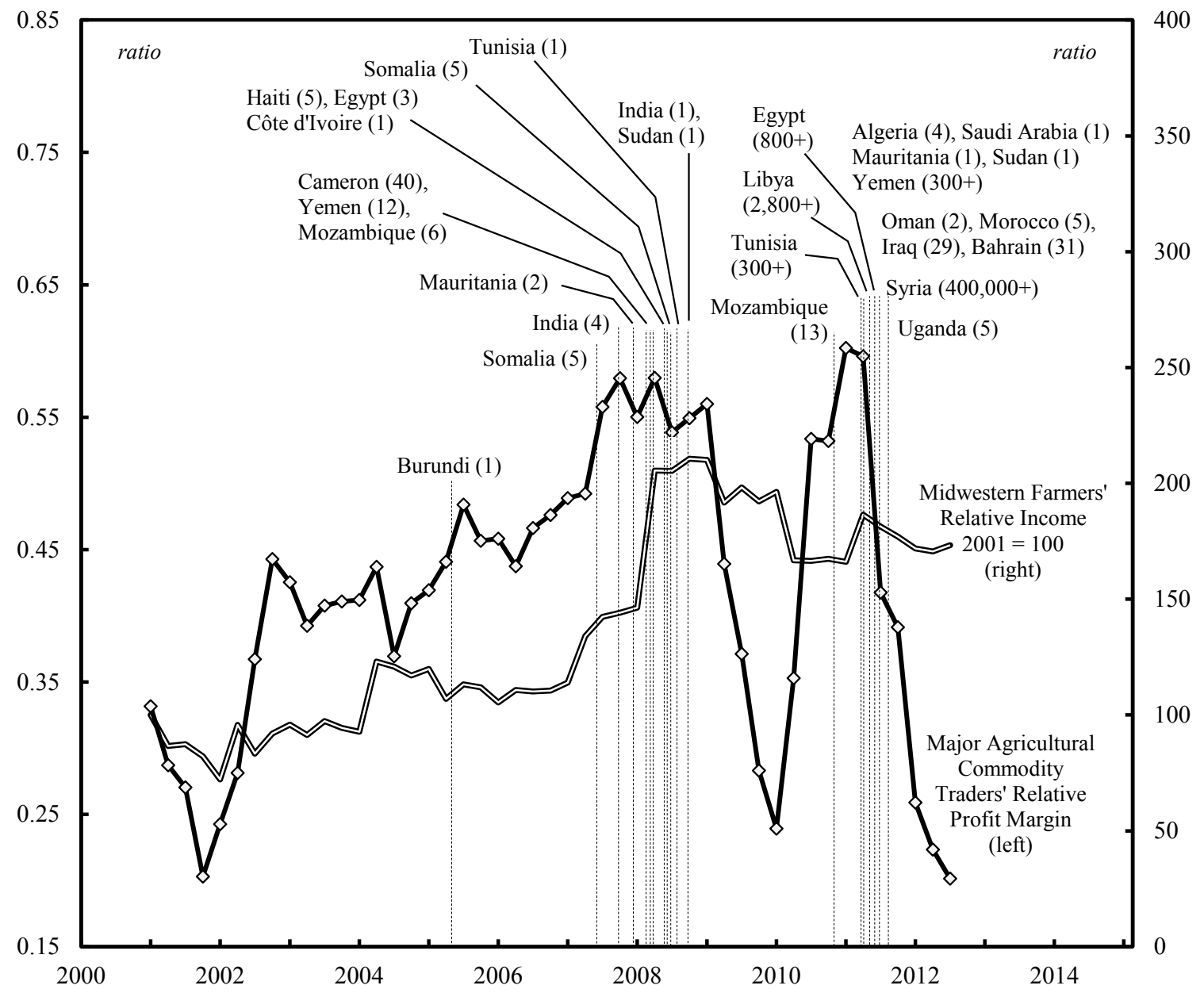

Figure 9: The Relative Profitability of Traders and Farmers and the Incidence of Revolt

Note: The major agricultural commodity traders comprise: Archer Daniels Midland, Bunge and Cargill. Differential markup is calculated by dividing the weighted average profit ratio of sales of these three companies by the weighted average profit ratio of sales of the Compustat 500. The Compustat 500 is the 500 largest firms by net income ranked for each quarter. Differential markup data presented as a oneyear moving average. The dashed vertical lines correspond to the beginning dates of food riots as well as protests associated with the Arab Spring. Death tolls reported in parentheses.

Source: Archer Daniels Midland, Bunge and Compustat 500 net income data from Compustat through WRDS. Cargill quarterly net income data from Factiva database and Cargill (2016). Revolt data from Lagi et al. (2011). For Midwestern farmers relative income data see Table 1. 


\section{CONCLUDING DISCUSSION}

This paper offers the contours of a power-distributional analysis of the financialization of food. While the international instability that has coincided with high and volatile food prices looms large in the periphery of my analytical gaze, the central focus of this investigation has been the domestic regulatory conflicts within the US agri-food sector. With this in mind, two sets of observations are worth underscoring. Firstly, the price dynamics in the 2000s have had highly uneven effects for agricultural producers. As a result, farm organizations have not formed a united front around derivatives reform. While small-scale farm groups, particularly cattle and wheat producers, have been highly vulnerable to price fluctuations and have thereby championed swift and extensive regulations; large-scale farm groups have generally prospered amid high and volatile prices and have become thoroughly integrated into the financialized food regime. Consequently, these large-scale farm groups have been predominantly obstructionist in the face of far-reaching reform. The divergent coalitional dynamics within the contemporary US agri-food sector contrast sharply with the broad and sustained agricultural mobilization against futures markets in the New Deal era. During this period, few farmers used futures to hedge risk, and speculation was widely considered to drive prices downward rather than upward. In consequence, agricultural producers of all varieties were more likely to view futures markets as a source of improvidence and immiseration rather than potential security and material gain.

Secondly, the historical analysis of the paper also reveals that hedging and speculation are not objectively classifiable. Rather, the borderline that separates hedging and speculation - and the concomitant boundary between those subject to position limits and those exempt from them - is historically mutable. In previous decades the regulatory definition of hedging was broadened so that it encompassed not only the potentially speculative activities of putatively commercial entities, but also the apparently riskreducing operations of nominally financial firms. After the fallout of the food and financial crises of 2007-08, much of the regulatory debate has revolved around the possible reversal of this trend. However, these debates are not occurring between equal interlocutors. After an initial flurry of advocacy activity from the stability alliance, the self-regulation alliance appears to have regained the initiative as dysfunctions in derivatives markets have temporarily subsided and as regulatory deliberations have become increasingly esoteric. If restrictions on speculation are compromised as a result, then during the next surge in agricultural prices speculative pressures may once again be a possible contributor to market turmoil and concomitant societal breakdown.

In terms of the broader study of financial regulatory policymaking, the analysis of the ambiguous borders that demarcate those targeted by regulation from those exempted from it opens up multiple avenues for inquiry. For example, there is ample scope for complementary research on how the boundaries that separate 'proprietary trading' from 'market making' have been disputed during the implementation of the Volcker Rule. And parallel investigations could also be conducted on historical conflicts around the regulatory differentiation of 'investment banking' and 'commercial banking'. Moreover, 
definitional contests around the category of 'swap dealer' in derivatives regulation, and around the category of 'systematically important financial institutions' in global macroprudential regulation are also deserving of scholarly attention. Finally, investigations could be conducted on how the expansion of banks and hedge funds into physical commodities trading in recent years has also unsettled existing regulatory divisions. With these considerations in mind, this paper presents the beginnings of a research agenda that explores how the activities of market participants and the architecture of regulation are dynamically co-constituted amid ongoing definitional contestation and distributional conflict. Ideally, this project could help us identify the regulatory lacuna from which future crises may originate. But at the very least, it will make us more reflexive about dualities that might sometimes be taken as pre-given in IPE, such as speculation and hedging, and perhaps most fundamentally of all, finance and commerce.

\section{ACKNOWLEDGEMENTS}

I would like to thank the editorial board and the three anonymous reviewers for their very insightful comments. Their input strengthened the paper considerably. Furthermore, I am extremely grateful to Sandy Brian Hager for helping me develop the research skills that make an investigation like this possible, and to David Ravensbergen and Joel Roberts for assisting me with the preparation of the manuscript. Final thanks are due to Jonathan Nitzan and Shimshon Bichler for their phrase 'accumulating through crisis', which I adapt for the title of this article, and for their research ethos, which inspires the rest of it. Any errors in this text are exclusively my own.

\section{DISCLOSURE STATEMENT}

No potential conflict of interest was reported by the author.

\section{NOTES}

1. As Hansen (1991: 84) argues the US government treated agricultural commodity traders with 'antagonism and scorn' during this period. The scorn was evidenced by the fact that, under the 1933 Agricultural Adjustment Act, the price supports for farmers were to be funded by a tax on grain processors. This tax provision, however, was ruled unconstitutional by the Supreme Court (Winders, 2009). In another expression of government hostility, just one year after the passing of the 1937 Commodity Exchange Act, Cargill, one of the major agricultural commodity traders, was accused by the 
Secretary of Agriculture, Henry Wallace, of market manipulation in corn futures trading. Cargill was subsequently banned from the Chicago Board of Trade, and it did not return to the exchange for two decades (Broehl, 1992).

2. In clear evidence that the commodity traders were no longer just subverting US trade policy, but actively setting it, the Agreement on Agriculture was originally drafted by Cargill's former vice-president, Daniel Amstutz (Winders, 2009).

3. The table does not include a data breakdown of what the USDA calls 'residence farms' - those small farms owned by operators who are either retired or whose primary occupation lies outside of farming. Additionally, it presents information on mean incomes rather than median incomes due to the lack of data on the latter. But we do know that in, 2014 the median income of large-scale commercial farms was US $\$ 225,463$ (USDA, 2014c). Although this is much lower than the mean figure because of the right-skewed distribution of income, it easily surpasses the income threshold of the top 5 percent of US households: US $\$ 165,500$ (Saez, 2015).

4. According to one survey, it was found that 44 percent of farmers with gross sales in excess of US $\$ 500,000$ hedge using futures, but just 34 percent of farmers with gross sales in the range of US $\$ 100,000-\$ 250,000$ follow suit (GAO, 1999: 24).

5. For more evidence of the possibly speculative character of futures trading activities of 'hedgers', see Cheng and Xiong (2014).

6. Other key conflicts revolved around spot and non-spot month position limit levels, along with clearing, margining and reporting requirements.

7. The complex causal pathways linking high and volatile food prices to social unrest are discussed by Patel and McMichael (2009) and Barrett (2013).

\section{NOTES ON CONTRIBUTOR}

Joseph Baines is a Lecturer in International Political Economy at King's College London.

Email: joseph.baines@kcl.ac.uk

\section{REFERENCES}

Acworth, W. (2011) FIA Annual Volume Survey 2010, Washington, DC: Financial Industry Association Press Release. March 2011; accessed at https://secure. fia.org/downloads/Volume-Mar_FI(R).pdf, 31 July 2016.

Acworth, W. (2014) FIA Annual Volume Survey 2013, Washington, DC: Financial Industry Association Press Release. March 2015; accessed at https://secure. fia.org/downloads/FIA_Annual_Volume_Survey_2013.pdf, 31 July 2016.

Acworth, W. (2015) FIA Annual Volume Survey 2014, Washington, DC: Financial Industry Association Press Release. March 2015; accessed at https://fimag. fia.org/articles/2014- 
fia-annual-global-futures-and-options-volume-gainsnorth-america-and-europe-offset, 31 July 2016.

American Farm Bureau Federation (AFBF). (2014) 'Letter to CFTC re: position limits for derivatives', Washington DC. 10 February 2014; accessed at http:// comments.cftc.gov/Handlers/PdfHandler.ashx?idD25428, 31 August 2014.

Arbit, T., Banaei, S., Loesch, M. and Sherman, J. (2013, November 8) 'CFTC approves new speculation position limits and aggregation proposals', Norton Rose Fulbright, 8 November 2013; accessed at http://www.nortonrosefulbright.com/knowledge/publicatio ns/108040/cftc-approves-new-speculative-position-limits-aggregation-proposals, 18 August 2014.

Baines, J. (2014) 'Food price inflation as redistribution: towards a new analysis of corporate power in the world food system', New Political Economy 19(1): 79- 112.

Barrett, C. B. (2013). Food Security and Sociopolitical Stability, Oxford: Oxford University Press.

Becker, G. S. (2008) 'Livestock feed costs: concerns and options', CRS Report for Congress, 17 September; accessed at http://congressionalresearch.com/RS22908/ document.php?studyDLivestockCFeedCCostsCConcernsCandCOptions, 21 March 2014.

Berkovitz, D. M. (2009) 'Position limits and the hedge exemption, brief legislative history'; accessed at http://www.cftc.gov/PressRoom/SpeechesTestimony/ berkovitzstatement07 2 809, 31 July 2016.

Bloomberg L. P. (2014) 'Segment data for Cargill 2007-2014'; accessed 8 May 2015 from Bloomberg Terminal database. Blosfield, E. and Osipovich, A. (2016) 'CFTC moving to amend position limits rule, sources say', Risk Magazine, 17 May; accessed at http://www.risk.net/energy-risk/news/2458386/cftc-moving-to-amend-position-limitsrule-sources-say, 31 July 2016.

Bonnen, J. T., Browne, W. P. and Schweikhardt, D. B. (1996) 'Further observations on the changing nature of national agricultural policy decision processes, 1946-1995', Agricultural History 70(2): 130-52.

Breger Bush, S. (2012) Derivatives and Development: A Political Economy of Global Finance, Farming, and Poverty, Basingstoke: Springer.

Broehl, W. G. (1992) Cargill: Trading the World's Grain, Hanover, NH: University Press of New England.

Broehl, W. G. (1998) Cargill: Going Global, Hanover, NH: University Press of New England.

Broehl, W. G. (2008) Cargill: From Commodities to Customers, Hanover, NH: University Press of New England.

Burch, D. and Lawrence, G. (2009) 'Towards a third food regime: behind the transformation', Agriculture and Human Values 26(4): 267-79.

Burghardt, G. and Acworth, W. (2009) FIA Annual Volume Survey 2008, Washington, DC: Financial Industry Association Press Release. March 2009; accessed at https://secure.fia.org/downloads/March_Volume(REV-2).pdf, 31 July 2016.

Bush, R. (2010) 'Food riots: poverty, power and protest', Journal of Agrarian Change 10(1): $119-29$. 
Bush, R. and Martiniello, G. (2017) 'Food riots and protest: agrarian modernizations and structural Crises', World Development 91: 193-207.

Cargill. (2011) 'Testimony of Todd Thul risk manager, Cargill AgHorizons to the House Committee on Agriculture', 12 October 2011; accessed at https://agricul ture.house.gov/sites/republicans.agriculture.house.gov/files/pdf/hearings/Thul111012.p df, 18 September 2014.

Cargill. (2016) Financial Information; Minneapolis, MN: Cargill; accessed at http:// www.cargill.com/company/financial/, 31 July 2016.

Carter, S. B. (2006) Historical Statistics of the United States: Earliest Times to the Present, Cambridge: Cambridge University Press.

Cheng, I. W. and Xiong, W. (2014) 'Why do hedgers trade so much?', Journal of Legal Studies 43: 183-207.

Clapp, J. (2014) 'Financialization, distance and global food politics', Journal of Peasant Studies 41(5): 797-814.

Clapp, J. and Helleiner, E. (2012) 'Troubled futures? The global food crisis and the politics of agricultural derivatives regulation', Review of International Political Economy 19(2): 181-207.

Coalition for Derivatives End-Users. (2010) Letter to CFTC, Re: Advanced Notice of Proposed Rulemaking. File no. S7-16-10, Washington, DC: CDEU; 20 September 2010; accessed at http://businessroundtable.org/resources/letter-to-secretary-elizabethmurphy-and-secretary-david-stawick-on-de, 31 July 2016.

Coalition for Derivatives End-Users. (2016) Coalition Members; Washington, DC: CDEU; accessed at http://coalitionforderivativesendusers.com/AboutUs/ coalition-members, 31 July 2016.

Commodity Futures Trading Commission (CFTC). (1977) Farmers' Use of Futures Markets and Forward Contracts - 1977 report, Washington, DC: US Government Printing Office; 16 March.

Commodity Futures Trading Commission (CFTC). (1979-2004) Annual Reports 19792004, Washington, DC: US Government Printing Office.

Commodity Futures Trading Commission (CFTC). (2016a) Disaggregated Futures and Options Combined Reports; Washington, DC: US Government Publishing Office; accessed at http://www.cftc.gov/MarketReports/CommitmentsofTraders/HistoricalCom pressed/index.htm, 31 July 2016.

Commodity Futures Trading Commission (CFTC). (2016b) Public Comments; Washington, DC: US Government Publishing Office; accessed at http://com ments.cftc.gov/PublicComments/CommentList.aspx, 31 July 2016.

Commodity Markets Council (CMC). (2014) 'Letter to the CFTC, re: position limits for derivatives; aggregation of positions', Washington, DC: CMC; 10 February 2014; accessed at http://www.commoditymkts.org/wp-content/uploads/2014/05/CMCPosition-Limits-Comment-Letter-2-10-2014.pdf, 21 August 2014.

Commodity Markets Oversight Coalition (CMOC). (2010) 'Letter to the CFTC re: general comments on implementation of title VII the Dodd-Frank act', 1 November 2010; accessed at http://www.nefiactioncenter.com/PDF/cmoc_doddfrank_gencomments _2010nov01.pdf, 19 August 2014. 
Commodity Markets Oversight Coalition (CMOC). (2015) 'Letter to CFTC re: 'reopening of comments periods, notice of proposed rulemaking, position limits for derivatives and aggregation of positions'; accessed at http://www.ieca-us.com/wpcontent/uploads/CMOC_PosLimitsLtr_03.30.15.pdf, 31 July 2016.

Ederer, S., Heumesser, C. and Staritz, C. (2016) 'Financialization and commodity prices an empirical analysis for coffee, cotton, wheat and oil', International Review of Applied Economics 30(4): 462-87.

Engel, A. (2013) 'Futures and risk: the rise and demise of the hedger-speculator dichotomy', Socio-Economic Review 11(3): 553-76.

Food and Agricultural Organization Statistical Division (FAOSTAT). (2014). Trade Data. FAO Statistics Division; Rome, Italy: FAO; accessed at http://faostat.fao. org/site/535/DesktopDefault.aspx?PageIDD535\#ancor, 31 July 2014.

Friedmann, H. (1993) 'The political economy of food: a global crisis', New Left Review I(197): 29-57.

Friedmann, H. and McMichael, P. (1989) 'Agriculture and the state system: the rise and decline of national agricultures, 1870 to the present', Sociologia Ruralis 19(2): 93-117.

Government Accountability Office (GAO). (1999) 'Agriculture in transition: farmers' use of risk management strategies'; accessed at http://www.gao.gov/ products/RCED-99-90, 31 July 2016.

Ghosh, J. (2010) 'The unnatural coupling: food and global finance', Journal of Agrarian Change 10(1): 72-86.

Hansen, J. (1991) Gaining Access: Congress and the Farm Lobby, 1919-1981, Chicago, IL: University of Chicago Press.

Hart, J. F. and Mayda, C. (1998) 'The industrialization of livestock production in the united states', Southeastern Geographer 38(1): 58-78.

Helleiner, E. (2014) The Status Quo Crisis: Global Financial Governance After the 2008 Meltdown, Oxford: Oxford University Press.

Hieronymous, T. (1976) The Economics of Futures Trading, New York, NY: Commodity Research Bureau.

Hoffman, N. and Aulerich, L. (2013) 'USDA economic research service - FDS13L- 01'; accessed at http://www.ers.usda.gov/publications/fds-feed-outlook/ fds131-01.aspx, 31 July 2016.

Hoppe, R. (2014) 'USDA economic research service - EIB132'; accessed at http:// www.ers.usda.gov/publications/eib-economic-information-bulletin/eib132.aspx, 31 July 2016.

International Swaps and Derivatives Association (ISDA). (2011) List of ISDA Primary Membership. Wasington, DC: ISDA; 10 February 2011; accessed at http://www.isda.org/membership/list_of_primary.html, 31 July 2016.

International Swaps and Derivatives Association (ISDA). (2016) ISDA Members. Wasington, DC: ISDA; 10 February 2011; accessed at http://www2.isda.org/ membership/members-list/, 31 July 2016.

Irwin, S. H. and Sanders, D. R. (2010) 'The impact of index and swap funds on commodity futures markets: Preliminary results', OECD Food, Agriculture and Fisheries Papers, No. 
27, New York: OECD Publishing, pp. 1-30; accessed at https://doi.org/10.1787/5kmd40wl1t5f-en, 31 July 2016.

Irwin, S. H., Sanders, D. R. and Merrin, R. P. (2009) 'Devil or angel? The role of speculation in the recent commodity price boom (and bust)', Journal of Agricultural and Applied Economics 41(2): 377-91.

Isakson, S. R. (2014) 'Food and finance: the financial transformation of agro-food supply chains', Journal of Peasant Studies 41(5): 749-75.

Isakson, S. R. (2015) 'Derivatives for development? Small-Farmer vulnerability and the financialization of climate risk management', Journal of Agrarian Change 15(4): 56980 .

Kneen, B. (2002) Invisible Giant: Cargill and its Transnational Strategies, London: Pluto Press.

Knorr, B. (2007) 'Hate speculators?', Farm Futures March 2007: 20.

Lagi, M., Bertrand, K. Z. and Bar-Yam, Y. (2011) The Food Crises and Political Instability in North Africa and the Middle East, Cambridge, MA: New England Complex Systems Institute. 11 August; accessed at http://arxiv.org/pdf/ 1108.2455.pdf, 31 July 2016.

Lappé, F. M. (1981) 'Testimony on behalf of the Institute for Food and Development Policy to the Subcommittee on Department Operations, Research, and Foreign Agriculture of the Committee on Agriculture', Washington, DC: House of Representatives, Ninetyseventh Congress, first session, US Printing Office, 28 July 1981.

Lawrence, F. (2011) 'The global food crisis: ABCD of food-how the multinationals dominate trade', The Guardian. 2 Jun; accessed at https://www.theguardian.com/globaldevelopment/poverty-matters/2011/jun/02/abcd-food-giantsdominate-trade, 31 July 2016.

MacDonald, J. M. (2008) 'The economic organization of US broiler production. USDA economic research service - EIB38'; accessed at http:/www.ers.usda. gov/publications/eib-economicinformation-bulletin/eib38.aspx, 31 July 2016.

Markham, J. (2014) Law Enforcement and the History of Financial Market Manipulation, New York, NY: Routledge.

Mahoney, J. and Thelen, K. (2010) 'A theory of gradual institutional change', in J. Mahoney and K. Thelen (eds) Explaining Institutional Change Ambiguity, Agency, and Power, Cambridge: Cambridge University Press, pp. 1-37.

Mayhew, R. (2012) 'Using futures \& options to risk manage the increasing influence of the outside markets on our commodity prices', Presentation Oil and Fats Seminar. 22 November; accessed at http://www.adm.com/en-US/products/food/oils/Documents/Rich ard\%20Mayhew\%20-\%20ADM\%20Investor.pdf, 31 July 2016.

McBride, W. D. and Matthews Jr., K. (2011) 'The diverse structure and organization of U.S. Beef cow-calf farms', Economic Research Service Economic Information System (73): 1-42. March 2011; accessed at http://www.ers.usda.gov/media/335292/dateliners_april2 011_1_.pdf, 31 July 2016.

Moschella, M. (2010) 'Back to the drawing board: the international financial architecture exercise', Review of International Political Economy 17(1): 155-71. 
Murphy, S., Burch, D. and Clapp, J. (2012) 'Cereal secrets: the world's largest grain traders and global agriculture', Oxfam Research Reports, August 2012; accessed at http://www.oxfam.org/sites/www.oxfam.org/files/rr-cerealsecrets-grain-tradersagriculture-30082012-en.pdf, 10 August 2014.

National Corn Growers Association (NCGA) and the National Gas Suppliers Association (NGSA). (2011a) 'Letter to house committee on agriculture, re: NCGA and NGSA support passage of H.R. 1573 to facilitate implementation of title VII of Dodd-Frank wall street reform and consumer protection act', 3 May 2011; accessed at http://www.ncga.com/upload/files/documents/pdf/dodd.frank.ncga_ngsa_letter_support ing_hr1573_final_05032011.pdf, 18 August 2014.

National Corn Growers Association (NCGA) and the National Gas Suppliers Association (NGSA). (2011b) 'Press release: natural gas companies and corn growers urge congress to grant more time and proper sequencing for CFTC financial reform rules', 3 May 2015; accessed at http://www.ngsa.org/download/news/news-2011/06\%20 \%20NGSA\%20and\%20Corn\%20Support\%20Sequencing\% 20Bill.pdf, 31 July 2016.

National Farmers Union (NFU). (2011) 'Letter to CFTC, re: position limits of derivatives; proposed rule, 76 Fed. Reg. 4752', 26 January 2011; accessed at http://comments.cftc.gov/PublicComments/ViewComment.aspx?idD33951\&SearchTex tDnational\%20farmers\%20union, 31 July 2016.

National Farmers Union (NFU). (2013) 'Letter to senate committee on agriculture, nutrition and forestry, RE: reauthorization of the CFTC', 1 May 2013; accessed at http://www.agriculture.senate.gov/imo/media/doc/National\%20Farmers \%20Union.pdf, 31 July 2016.

Newman, S. A. (2009) 'Financialization and changes in the social relations along commodity chains: the case of coffee', Review of Radical Political Economics 41 (4): 539-59.

Nitzan, J. and Bichler, S. (2009) Capital as Power: A Study of Order and Creorder, Milton Park, Abingdon, Oxon: Routledge.

Pashigian, B. P. (1988) 'Why have some farmers opposed futures markets?' Journal of Political Economy 96(2): 371-82.

Pagliari, S. and Young, K. L. (2014) 'Leveraged interests: Financial industry power and the role of private sector coalitions', Review of International Political Economy 21(3): 575610.

Paul, A. (1976) 'Treatment of hedging in commodity market regulation', Economics Research Service, United States Department of Agriculture. Technical Bulletin, No. 1538: 1-27.

Patel, R. and McMichael, P. (2009) 'A political economy of the food riot', Review (Fernand Braudel Center) 32(1): 9-35.

Pleven, L. (2012) 'Behind corn's squeeze play: farmers', Wall Street Journal. 25 November 2012; accessed at http://online.wsj.com/news/articles/SB1000142405297020477860 4577243491711608130,31 July 2016.

Romano, R. (1997) 'The political dynamics of derivative securities regulation', Yale Journal of Regulation (14): 279-406. 
Ranchers-Cattlemen Action Legal Fund, United Stockgrowers of America (RCALF). (2011) 'Letter to the CFTC Re: comments concerning position limits for derivatives: notice of proposed rulemaking', 28 March 2011; accessed at http://www.rcalfusa.com/Trade/110328-CommentsCFTCProposedRuleonPositionLimits.pdf, 19 August 2014.

Saez, E. (2015) Striking it Richer: The Evolution of Top Incomes in the United States, Berkeley, CA: University of California. Accessed at https://eml.berkeley. edu/»saez/saez-UStopincomes-2013.pdf, 12 December 2015.

Salerno, T. (2016) 'Cargill's corporate growth in times of crises: how agro-commodity traders are increasing profits in the midst of volatility', Agriculture and Human Values 34(1): 211-22.

Schuh, G. E. (1974) 'The exchange rate and U. S. agriculture', American Journal of Agricultural Economics 56(1): 1-13.

Scott-Villiers, P., Chisholm, N., Wanjiku, K. and Hossain, N. (2016) 'Precarious lives: work, food and care after the global food crisis', Oxfam Research Report. UK: Institute of Development Studies, University of Sussex, pp.1-76. Accessed at http://policypractice.oxfam.org.uk/publications/precarious-lives-workfood-and-care-after-theglobal-food-crisis-620020, 20 December 2016.

Shanmugam, V. and Armah, P. (2012) 'Role of speculators in agricultural commodity price spikes during 2006-2011', Academy of Accounting and Financial Studies Journal 16: 97-114.

Strange, S. (1988). States and Markets, London: Pinter. Streeck, W. and Thelen, K. (2005) 'Introduction: institutional change in advanced political economies', in W. Streeck and K. Thelen (eds) Beyond Continuity: Institutional Change in Advanced Political Economies, Oxford: Oxford University Press.

Tsingou, E. (2015) 'Transnational veto players and the practice of financial reform', British Journal of Politics \& International Relations 17(2): 318-34.

United States Department of Agriculture (USDA). (1941-1996) Agricultural Statistics, Washington, DC: Department of Agriculture.

United States Department of Agriculture (USDA). (2014a) 2012 Census of Agriculture, US and State Data. Washington, DC: Department of Agriculture. Accessed at https://www.agcensus.usda.gov/Publications/2012/Full_Report/Volume_1,_Chapter_1_ US/usv1.pdf

United States Department of Agriculture (USDA). (2014b) American Indian Farmers, US Census Highlights. Washington, DC: Department of Agriculture. Accessed at https://www.agcensus.usda.gov/Publications/2012/Online_Resources/Highlights/Ameri can_Indian_Farmers/Highlights_American_In dian_Farmers.pdf, 31 July 2016.

United States Department of Agriculture (USDA). (2014c) Agricultural Resource Management Survey. Washington, DC: Department of Agriculture. Accessed at www.ers.usda.gov/datafiles/Farm_Household_Income/table02.xls, 31 July 2016.

United States Department of Agriculture (USDA). (2016a) Agricultural Resource Management Survey Database, Washington, DC: US Publishing Office. Accessed at http://www.ers.usda.gov/data-products/arms-farm-financialand-crop-productionpractices/arms-data.aspx, 31 July 2016. United States Department of Agriculture 
(USDA). (2016b) Feed Grains Database., Washington DC: US Publishing Office. Accessed at http://www.ers.usda. gov/data-products/wheat-data.aspx\#25377, 31 July 2016. United States Department of Agriculture (USDA). (2016c) Wheat Data., Washington, DC: US Publishing Office. Accessed at http://www.ers.usda.gov/dataproducts/wheatdata.aspx\#25377, 31 July 2016.

United States Senate. (2006) The Role of Market Speculation in Rising Oil and Gas Prices: a Need to Put the Cop Back on the Beat, Staff Report, Permanent Subcommittee on Investigations, Washington, DC: U.S. Senate, S. Prt. No. 109-65, 27 June.

United States Senate. (2007) Excessive Speculation in the Natural Gas Market, Staff Report, Permanent Subcommittee on Investigations of the Senate Committee on Homeland Security and Governmental Affairs, Washington, DC: U.S. Senate, 25 June.

United States Senate. (2009) Excessive Speculation in the Wheat Market, Majority and Minority Staff Report, Permanent Subcommittee on Investigations, Washington, DC: US Senate, 24 June.

US Wheat Associates (USW). (2008) Wheat Letter. Washington DC: USW, 2 October; accessed: http://www.uswheat.org/wheatLetter/doc/384579D8AD24670D85257C1500 61C68E?OpenDocument, 31 July 2016.

Van der Zwan, N. (2014) 'Making sense of financialization', Socio-Economic Review 12(1): 99-129.

Williams, J. W. (2014) 'Feeding finance: a critical account of the shifting relationships between finance, food and farming', Economy and Society 43(3): 401-31.

Winders, B. (2009) The Politics of Food Supply: US Agricultural Policy in the World Economy, New Haven: Yale University Press.

Winders, B., Heslin, A., Ross, G., Weksler, H. and Berry, S. (2015) 'Life after the regime: market instability with the fall of the US food regime', Agriculture and Human Values 33(1): 73-88.

Ziegler, J. N. and Woolley, J. T. (2016) 'After Dodd-Frank ideas and the post-enactment politics of financial reform in the United States', Politics \& Society 44(2): 249-80. 